DOI: https://doi.org/10.47405/mjssh.v5i10.522

\begin{tabular}{|c|c|}
\hline 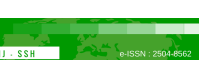 & Malaysian Journal of Social Sciences and Humanities (MJSSH) \\
\hline Malaysian Journal of & Volume 5, Issue 10, October 2020 \\
\hline (MJ-SSH) & e-ISSN : 2504-8562 \\
\hline & $\begin{array}{l}\text { Journal home page: } \\
\text { www.msocialsciences.com }\end{array}$ \\
\hline
\end{tabular}

\title{
Faktor-faktor yang Mempengaruhi Tekanan Kerja di kalangan Kakitangan Hospital Kerajaan
}

\author{
Cyrill Frederick Ganing1, Mohammad Mujaheed Hassan1, Wan Nur Nazihah Wan Hamzah'
}

${ }^{1}$ Jabatan Sains Kemasyarakatan dan Pembangunan, Fakulti Ekologi Manusia, Universiti Putra Malaysia (UPM)

Correspondence: Mohammad Mujaheed Hassan (mujaheed@upm.edu.my)

\begin{abstract}
Abstrak
Tekanan pekerjaan ialah tekanan yang berpunca daripada atau melibatkan pekerjaan. Tekanan yang negatif, baik dari segi mental, fizikal atau emosi, merupakan satu faktor penting yang boleh menggugat keharmonian kualiti kehidupan seseorang pekerja. Tekanan merupakan satu reaksi negatif manusia terhadap rangsangan daripada sosial, suasana pekerjaan, ganjaran yang tidak mencukupi, gaya hidup yang terlalu mendesak dan sebagainya.Laporan yang dikeluarkan oleh Pertubuhan Bangsa-Bangsa Bersatu (PBB) menyatakan bahawa tekanan kerja merupakan penyumbang terbesar terhadap lima penyakit utama di dunia iaitu penyakit jantung, kemurungan melampau, strok, penyakit paru-paru yang kronik dan kencing manis menjelang tahun 2020. Astro AWANI juga dalam laporannya bertarikh 26hb. Disember 2018 melaporkan, jika tiada langkah proaktif atau pencegahan diambil di peringkat awal bagi mengatasi masalah tekanan yang berlaku berkenaan, pelbagai kesan atau impak negatif yang boleh berlaku terutamanya dari sudut kesihatan pekerja seperti darah tinggi, kemurungan, masalah jantung, serta kematian. Maka dari itu, kajian ini adalah untuk mengenalpasti faktor-faktor tekanan kerja di kalangan kakitangan hospital kerajaan Sibu, Sarawak Objektif kajian ini mencakupi enam persoalan iaitu i) memperihalkan latar belakang responden; ii) mengenalpasti faktor tekanan kerja yang utama; iii) mengenalpasti tahap tekanan kerja di kalangan kakitangan Hospital Sibu, Sarawak; iv) mengkaji perhubungan antara faktor tekanan kerja dengan tahap tekanan kerja; v) menentukan perbezaan antara demografi dengan tahap tekanan kerja; dan vi) menentukan perbezaan antara demografi dengan faktor tekanan kerja. Seramai 322 orang yang terdiri daripada kakitangan Hospital Kerajaan Sibu, Sarawak sebagai sampel kajian. Kajian ini menggunakan kaedah kuantitatif yang menggunakan soal selidik untuk mengumpul data. Borang soal selidik terbahagi kepada tiga bahagian iaitu latar belakang responden, faktor tekanan kerja dan tahap tekanan kerja. Data dianalisis deskriptif, ujian t, korelasi pearson dengan menggunakan 'Statistical Package for Social Science' (SPSS) versi 25. Terdapat enam faktor tekanan kerja iaitu struktur dan iklim organisasi, halangan rumah dan kerja, peranan pengurusan, kerjaya dan pencapaian, hubungan tempat kerja dan intrinsik. Hasil kajian menunjukkan bahawa faktor tekanan kerja yang utama adalah struktur iklim dan organisasi dengan nilai min 3.1016. Manakala, terdapat perhubungan yang signifikan serderhana antara faktor tekanan kerja dengan tahap tekanan kerja. Analisis juga mendapati bahawa terdapat perbezaan yang signifikan antara faktor tekanan kerja dengan status perkahwinan dan waktu bekerja.
\end{abstract}

Kata kunci: faktor tekanan, tekanan kerja, kakitangan hospital kerajaan

\section{Factors Influencing Stress at Work Among Government Hospital Staff}

\section{Abstract}


Stress at work is the pressure that results from or involves work. Negative stress, whether mental, physical or emotional is an important factor that can threaten the quality of life of an employee. Stress is a negative reaction to social stimuli, work environment, inadequate rewards, overworked lifestyle and so on. The United Nations (UN) report states that work stress is the biggest contributor to the five major illnesses in the world of heart disease, chronic depression, stroke, chronic lung disease and diabetes by 2020. Astro AWANI is also in its report dated 26th. December 2018 reports that, if no proactive or preventive measures are taken in the first place to address the underlying stress, a variety of negative or negative effects can occur, especially in terms of workers' health such as high blood pressure, depression, heart problems, and death. Therefore, this study was to identify factors that influence stress at work among government hospital employees. The objectives of this study consists pf six questions which is i) to describe the background of the respondents; ii) to identify key factors of stress at work; iii) to identify the level of stress at work among the employees of Sibu Hospital, Sarawak; iv) to study the relationship between factorsof stress at work and job stress levels; v) to determine the difference between demographics and the level of stress at work; and vi) determine the difference between demographics and factors of stress at work. A total of 322 people are employees of Government Hospital Sibu, Sarawak as sample. The survey used questionnaires to collect data. The questionnaire was divided into three section which is respondents' background, factors of stress at work and job stress level. Data were analyzed using descriptive, $t$ test, pearson correlation using Statistical Package for Social Science (SPSS) version 25. There are six factors of stress at work namely organizational structure and climate, home and work barriers, management role, career and achievement, work relationship and intrinsic. The results show that the major factors of work pressure are climate and organizational structure with a mean value of 3.1016. However, there is a significant moderate relationship between factors of stress at work and job stress levels. The analysis found there are significant different between factors of stress at work with marital status and working hours.

Keywords: stress factors, stress at work, government hospital employees

\section{Pengenalan}

Tekanan pekerjaan ialah tekanan yang berpunca daripada atau melibatkan pekerjaan. Tekanan yang negatif, baik dari segi mental, fizikal atau emosi, merupakan satu faktor penting yang boleh menggugat keharmonian kualiti kehidupan seseorang pekerja. Tekanan merupakan satu reaksi negatif manusia terhadap rangsangan daripada sosial, suasana pekerjaan, ganjaran yang tidak mencukupi, gaya hidup yang terlalu mendesak dan sebagainya. Selain itu juga ada juga tekanan dialami secara sederhana dan mampu memotivasikan individu untuk mencapai matlamat dan berjaya dalam usaha yang dilaksanakan.

Dasar Buruh Negara digubal selaras dengan perubahan teknologi ekonomi dan sosial yang sangat memerlukan strategi yang seimbang dengan isu-isu perburuhan dan tenaga manusia. Dasar ini yang mendukung prinsip tripartisma di antara kerjaan, majikan dan pekerja akan menjamin keharmonian perhubungan perusahaan serta meninggikan mutu pengihidupan pekerja dan meningkatkan keupayaan dan persaingan tekanologi negara. Dasar Buruh Negara menetukan adanya strategi pekerjaan untuk semua orang, wujudnya tenaga kerja terlatih dan berkemahiran serta sanggup menerima perubahan, meningkatkan produktiviti perburuhan dan mengalakkan etika kerja yang baik, mewujjudkan suasana perhubungan perusahaan yang harmoni serta memastikan standard perburuhan dan penentuan keselamatan sosial responsive kepada usaha memperbaiki mutu penghidupan pekerja.

Tekanan di tempat kerja bukanlah seperti risiko di tempat kerja yang biasa (agen neurotoksid dan risiko ekonomi) malahan ianya tiada batasan jenis pekerjaan dan berpotensi member kesan ke atas risiko kesihatan kepada sesiapa sahaja. Apabila individu mengalami tekanan di tempat kerja, ianya boleh menyebabkan simpton yang menjejaskan fisiologi, psikologi dan gelagat. Tekanan kerja berlebihan yang berlaku di tempat kerja boleh menyebabkan masalah kesihatan pekerjaan yang kronik dialami oleh sumber manusia organisasi. Ini kerana apabila lebih 20 tahun, tekanan merupakan masalah kesihatan pekerjaan yang sangat penting. Kemurungan yang berpunca daripada tekanan sebenarnya 
boleh menjejaskan tahap kesihatan individu. Apabila pekerja berasa tertekan dan ianya terus berulang semasa melakukan tugas, maka kecenderungan mereka mendapat kecederaan atau kemalangan adalah tinggi.

Ini kerana tekanan boleh mempengaruhi pekerja dengan pelbagai cara iaitu mengurangkan daya ketahan terhadap penyakit, menganggu tidur serta menyebabkan hilang daya tumpuan. Apabila masalah ini berterusan, perkara ini boleh menyebabkan kecenderungan pekerja untuk melakukan kesilapan dan kecuaian yang membawa kepada kemalangan, kecederaan, kualiti produk yang rendah serta menjejaskan keseluruhan produktiviti organisasi. Di samping impak kronik seperti penyakit mental yang telah dijelaskan, tekanan di tempat kerja boleh menyebabkan seseorang individu berada dalam kemurungan, cepat marah dan tidak suka bergaul. Keadaan tekanan kerja yang berlebihan menyebabkan masalah ini berpanjangan sehingga ke rumah dan melibatkan pihak lain. Tekanan yang berlaku di tempat kerja boleh menyebabkan terbawanya tanda kebimbangan tersebut ke rumah. Ini boleh menganggu psikologi dan hubungan sosial seseorang itu.

\section{Penyataan Masalah}

Beberapa data statistik telah ditemui hasil daripada kajian lepas membuktikan bahawa kesan tekanan kerja mempunyai pengaruh yang kuat terhadap kesihatan pekerja. Sebagai contoh, kajian yang dijalankan oleh Kesihatan dan Morbiditi Kebangsaan (2001) menunjukkan statistik prevalen mengenai kadar kemurungan akibat daripada tekanan kerja menyumbang sebanyak 20\%. Manakala di peringkat antarabangsa, statistik melaporkan bahawa kira- kira 450 juta pekerja dikesan mengalami kemurungan yang serius. Seterusnya, laporan yang dikeluarkan oleh Pertubuhan Bangsa-Bangsa Bersatu (PBB) menyatakan bahawa tekanan kerja merupakan penyumbang terbesar terhadap lima penyakit utama di dunia iaitu penyakit jantung, kemurungan melampau, strok, penyakit paru-paru yang kronik dan kencing manis menjelang tahun 2020.

Astro AWANI juga dalam laporannya bertarikh 26hb. Disember 2018 melaporkan, Tahun Baru 2019 akan menjelang tiba. Sudah pastinya semua pengurusan organisasi dan tempat kerja khususnya pihak majikan kini sedang sibuk merangka sasaran kerja masing-masing melalui sistem Petunjuk Prestasi Utama atau lebih dikenali sebagai Key Performance Indicator (KPI) bagi memenuhi sasaran kerja sepanjang tahun 2019 yang akan datang. KPI adalah satu sistem pengukuran yang mudah, berkesan dan dapat membantu sesebuah organisasi menilai tahap kemajuan pekerja dan perkhidmatan yang ingin disampaikan di tempat kerja (Nordin dan Hassan, 2019). Dalam ayat pendek, KPI terbabit perlulah dirangka secara realistik atau berpijak di bumi yang nyata. Tidak dapat dinafikan setiap organisasi atau tempat kerja mempunyai objektif serta matlamat yang berbeza. Produktiviti sesebuah organisasi bergantung kepada kualiti prestasi kerja (Nordin dan Hassan, 2019). Jika KPI yang dirangka tidak menepati keadaan atau suasana organisasi atau tempat kerja ianya dikhuatiri akan melahirkan persekitaran pekerjaan yang dipenuhi dengan tekanan dan stres.

Jika tiada langkah proaktif atau pencegahan diambil di peringkat awal bagi mengatasi masalah tekanan atau stres yang berlaku berkenaan, pelbagai kesan atau impak negatif yang boleh berlaku terutamanya dari sudut kesihatan pekerja seperti darah tinggi, kemurungan, tekanan perasaan, masalah jantung, serta kematian. Tekanan dan stres yang berlaku juga boleh menjejaskan kehidupan peribadi pekerja yang terlibat. Tekanan dan stres yang berlaku juga boleh menjejaskan produktiviti seseorang individu itu serta memberi impak terhadap produktiviti dan hasil keuntungan sesebuah organisasi atau tempat kerja. Tekanan yang gagal dikendalikan dengan baik akibat daripada perlaksanaan KPI yang tidak realistik itu juga akan menjejaskan reputasi sesebuah organisasi atau tempat kerja berkenaan buat tmpoh jangka masa panjang. Akhirnya semua pihak akan menerima impak akibat kegagalan mereka membendung isu tekanan yang berlaku akibat daripada pelaksanaan KPI yang tidak realistik serta mustahil untuk dipenuhi terbabit.

Berita Harian dalam laporannya yang ditulis oleh Harun Yahya bertarikh 21hb. Julai 2017 menyatakan kesukaran menangani tekanan kerja didakwa antara punca lebih 20,000 penjawat awam bersara awal setiap tahun. Presiden Kongres Kesatuan Pekerja Dalam Perkhidmatan Awam (CUEPACS), Datuk 
Azih Muda, berkata, jumlah itu dikhuatiri terus meningkat jika tiada usaha dan langkah proaktif menanganinya. "Angka itu hampir menyamai jumlah penjawat awam yang bersara yang dianggarkan antara 30,000 hingga 35,000 setahun, antara puncanya adalah tekanan di tempat kerja," katanya. Beliau turut menyatakan, tekanan kerja akibat beban tugas yang banyak dengan kerja shif antara faktor utama memaksa penjawat awam bersara awal. Beliau berkata, desakan bersara awal itu didorong kegagalan penjawat awam dibayar elaun tambahan dan ada yang dibayar separuh daripada jumlah ditetapkan.

Di samping itu, dakwanya, tekanan kerja juga menyumbang kepada penceraian dan mengikut statistik, kadar penceraian yang paling tinggi direkodkan dalam sektor awam berbanding swasta. "Sekurangkurangnya sepasang suami isteri bercerai pada setiap hari akibat masalah rumah tangga kesan daripada bekerja shif disebabkan kesuntukan masa bersama keluarga. "Tekanan yang dihadapi penjawat awam ini juga berorientasikan dengan KPI (Petunjuk Prestasi Utama) dan bagi memastikan pekerja sektor awam sentiasa bersemangat untuk bertugas kebajikan serta keperluan mereka harus diberi perhatian,"katanya.

Bernama Online dalam laporannya bertarikh 8hb. November 2011 turut melaporkan hampir separuh pekerja Malaysia bekerja lebih 8 jam sehari dan membawa pulang kerja secara tetap untuk diselesaikan pada sebelah malam, demikian menurut dapatan kajian global terbaharu dari Regus. Regus, penyedia tempat kerja fleksibel terbesar di dunia telah mendapatkan maklum balas dari lebih 12,000 ahli perniagaan di 85 negara. Regus menyatakan bahawa alasan tekanan pada waktu bekerja yang boleh dipertikaikan telah meningkat sejak beberapa tahun kebelakangan disebabkan pemulihan ekonomi yang perlahan di ekonomi matang dan sebaliknya sangat pantas di ekonomi baharu muncul.

Kajian itu mendapati 32 peratus daripada pekerja Malaysia dan 38 peratus daripada pekerja global biasanya bekerja antara Sembilan hingga 11 jam setiap hari manakala 15 peratus pekerja di Malaysia bekerja secara tetap lebih 11 jam sehari berbanding dengan 10 peratus di seluruh dunia. Naib Presiden Regus Australia, New Zealand dan Asia Tenggara William Willems berkata kajian itu mendapati terdapat kekaburan mengenai garisan kerja dan rumah. Kesan jangka panjang terlebih kerja ini boleh merosakkan kesihatan pekerja dan produktiviti keseluruhan apabila para pekerja memaksa diri mereka bekerja teruk dan menjadi melawan, murung dan malah tidak sihat di segi fizikal, katanya.

"Sambil kajian kami mendapati pekerja yang bekerja di tempat yang jauh dan mudah bergerak dalam tempoh yang lama, wujud bukti yang menunjukkkan bahawa para pekerja yang bekerja di tempat yang jauh lebih produktif, mempunyai kepuasan bekerja dan paras tekanan yang rendah," katanya, sambil menyatakan para pekerja sedemikian biasanya kurang melakukan perjalan sekaligus membolehkan mereka menggunakan lebih banyak masa bagi pekerjaan masing-masing. Perniagaan yang membolehkan warga kerja masing-masing bekerja dari lokasi yang berdekatan rumah dan menguruskan masa secara bebas akan menyeimbangkan tekanan keseimbangan kerja dan kehidupan dan menjadi lebih produktif, komited dan lebih sihat.

Menurut Rohany \& Fatimah (2006), tekanan merupakan fenomena yang penting dan seringkali dikaitkan dengan prestasi kerja individu, tahap kesihatan dan produktiviti pekerja. Tekanan boleh menjejaskan produktiviti serta kualiti pekerja jika tidak ditangani dengan baik dan berkesan. Oleh itu, tekanan kerja boleh member kesan yang negatif terhadap kesihatan pekerja seterusnya kesejahteraan individu itu sendiri. Menurut Howard (2001) dipetik dalam Noira Azini Abidin, 2003, pekerja yang terlibat dalam bidang perubatan dan kejuruwatan mempunyai risiko yang tinggi untuk mengalami tekanan di tempat kerja. Ini kerana, jururawat khususnya perlu mencapai piawaian yang diperuntukkan oleh sesebuah badan kesihatan. Seorang jururawat bukan sahaja perlu mewujudkan hubungan interpersonal dengan pesakit dan penyelia.

\section{Objektif Kajian}

Objektif utama kajian adalah untuk mengetahui faktor-faktor yang mempengaruhi tekanan kerja di kalangan kakitangan hospital kerajaan di Sibu, Sarawak. Untuk mencapai objektif umum ini, empat objektif khusus telah dibentuk, iaitu: 
i. Memperihalkan latar belakang responden;

ii. Mengenalpasti tahap faktor tekanan kerja dan tahap tekanan kerja;

iii. Menetukan perhubungan antara faktor tekanan kerja dengan tahap tekanan kerja;

iv. Menentukan perbezaan antara faktor tekanan kerja, tahap tekanan kerja dengan latar belakang demografi.

\section{Kerangka Konseptual}

Rajah 1: Kerangka Konseptual Kajian

\section{Pombolehubah Terdahulu}

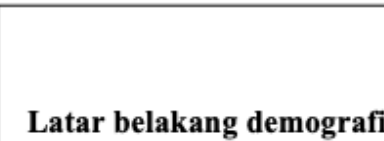

Jantina; umur; status perkahwinan; tempoh perkhidmatan; waktu bekerja

\section{Pombolehubah Tidak Bersandar}

Pombolehubah Bersandar

Tahap Tekanan Kerja

\section{Kajian Literatur}

Dari sudut pandangan psikoanalisis, Sigmund Freud berpendapat kebimbangan (anxiety) dan tekanan adalah berkaitan rapat. Menurut Sigmund Freud pekerja yang mengalami kebimbangan, di dalam bentuk realiti, moral dan neurotik kelazimannya akan berada di dalam keadaan tertekan. Tindak balas ini, boleh terjadi di dalam pelbagai bentuk simptom somatik seperti peningkatan denyutan jantung, berpeluh, menggigil dan kecut perut. Ahli psikoanalisis bernama Franz Alexender juga menyatakan bahawa tekanan merupakan satu bentuk penyakit psikosomatik. Beliau turut mengatakan bahawa tekanan yang disebabkan oleh ketegangan emosi adalah melibatkan konflik kesedaran (Lauzan, 1963) iaitu konflik ego, alam luaran serta id dan superego.

Menurut pandangan behaviouris, B. F Skinner menyatakan kebanyakan pekerja menunjukkan tingkahlaku tertekan telah diteguhkan melalui pengalaman lampau dan memberi tindakbalas terhadap rangsangan tersebut. Menurut B.F Skinner lagi, peneguhan yang diterima oleh pekerja berkemungkinan di dalam bentuk ganjaran seperti ingin dikasihani, dihargai atau diberi perhatian oleh kawan-kawan. Spence dan Spence (1956) mencadangkan bahawa sesuatu dorongan yang tinggi, akan menyebabkan peneguhan lebih cepat berlaku dan adalah lebih sukar tingkahlaku tersebut dihapuskan. Bagi Lazarus (1966) pula, tingkahlaku yang berkaitan dengan tekanan akan lebih dipengaruhi oleh proses pembelajaran. Menurut beliau keadaan ini akan bergantung pada sejauhmana kepayahan tingkahlaku pekerja itu dibentuk. Mahl (1971) mengatakan jika tingkahlaku itu mudah dibentuk maka senanglah pekerja untuk menghadapi tekanan.

Teori behaviourism ini mempunyai kebenarannya, hal ini dilihat jika seseorang pekerja seringkali dikasihani semasa mengalami tekanan, maka apabila mereka memerlukan perhatian, maka mereka seringkali secara sengaja meletakkan diri sendiri di dalam tekanan. Mandler (1979) mengatakan bahawa rangsangan tekanan akan dilihat sebagai tekanan apabila rangsangan tekanan itu melalui proses pemahaman, intepretasi, persepsi dan situasi ransangan itu didapati merbahaya dan boleh mengancam 
individu. Lazarus (1966) pula mempunyai pendapat bahawa rangsangan yang menghasilkan tekanan yang berbentuk psikologi, haruslah menunjukkan bahaya terhadap sistem psikologi dan difahami secara simbolik. Oleh yang demikian, jika seseorang pekerja itu mempersepsikan bahaya maka pekerja tersebut secara tidak langsung telah mengalami tekanan.

\section{Kajian Tempatan}

Aris et. al (2012), dalam kajiannya melihat Stress dalam Perkhidmatan Awam:Impaknya kepada Prestasi dan Kesejahteraan Pegawai Awam Seramai 2807 responden daripada pelbagai kementerian dan jabatan telah dipilih. Keputusan kajian menunjukkan tahap tekanan kakitangan awam berada pada tahap sederhana. Manakala faktor intrinsik dan struktur iklim dalam organisasi merupakan punca utama tekanan. Penemuan kajian juga menunjukkan daya tindak berbentuk spiritual paling banyak digunakan responden apabila berhadapan dengan tekanan kerja diikuti daya tindak berubah.

Dalam kajian yang telah dilakukan oleh Narimah (2003) bagi melihat hubungan di antara tekanan kerja dengan kepuasan kerja dan kesannya terhadap strategi daya tindakan di kalangan jururawat di hospital kerajaan dan swasta. Kajian ini juga bertujuan untuk melihat perbezaan tekanan kerja mengikut taraf perkahwinan, taraf pendidikan, umur dan tempoh bekerja. Seramai 160 orang jururawat daripada hospital kerajaan dan swasta telah dipilih sebagai subjek. Alat kajian yang digunakan ialah Occupational Stress Indicator (OSI). Data dianalisis dengan menggunakan kaedah Korelasi Pearson, Ujian-t dan Anova sehala. Keputusan kajian menunjukkan tidak terdapat hubungan megatif di antara tekanan dengan kepuasan kerja. Namun terdapat hubungan yang positif di antara tekanan dengan strategi daya tindak. Kajian ini juga mendapati tidak terdapat perbezaan tekanan kerja mengikut taraf perkahwinan, taraf akademik dan tempoh bekerja di kalangan jururawat. Namun terdapat perbezaan dari segi umur.

Manakala hasil kajian oleh Khairul Bariah (2003) untuk melihat hubungan tekanan kerja dengan aspek kepuasan kerja dan strategi dan strategi daya tindak dengan aspek kesihatan mental dan kesihatan fizikal di kalangan jururawat hospital swasta. Di samping itu juga kajiannya melihat kepada perbezaan tekanan kerja mengikut taraf akademik dan pengalaman kerja. Subjek kajian terdiri daripada 25 orang jururawat hospital swasta. Alat ujian yang digunakan ialah Occupational Stress Indicator (OSI). Data dianalisis dengan menggunakan Korelasi Pearson. Ujian-t dan Anova sehala. Dapatan kajian menunjukkan tidak terdapat perbezaan tekanan kerja di kalangan jururawat hospital dari segi taraf akademik dan pengalaman kerja. Manakala, tekanan kerja mempunyai hubungan negatif dengan kepuasan kerja , daya tindakan dan tahap kesihatan fizikal serta mental.

Lim (1998) pula mengkaji hubungan tekanan dengan kesihatan fizikal dan peranan sokongan sosial sebagai perantara di kalangan 117 orang pelajar tahun tiga di sebuah institusi pengajian tinggi. Keputusan mendapati terdapat perbezaan di antara pelajar lelaki dan perempuan dari segi tekanan dan kesihatan fizikal mereka. Kajian ini turut menunjukkan apabila tekanan kerja tinggi, kesihatan pekerja turut menurun. Lee juga (2002) telah menjalankan kajian tentang hubungan tekanan kerja dengan kepuasan kerja, lokus kawalan dan personaliti ke atas 100 orang pegawai polis. Hasil kajian mendapati apabila tekanan kerja tinggi, kepuasan kerja menurun dan apabila kepuasan kerja tinggi, personality turut positif. Sebaliknya, tiada terdapat hubungan di antara kepuasan kerja dan lokus kawalan.

Manakala kajian Thi (1998) tentang faktor tekanan di kalangan pengurus dan eksekutif di tempat kerja mendapati jangkaan tinggi, mengekalkan jangkaan tersebut, struktur organisasi yang tegar dan birokrasi merupakan punca-punca utama tekanan kerja di organisasi. Pengurus dan eksekutif perempuan mengalami tekanan kerja yang lebih tinggi berbanding dengan pengurus dan eksekutif lelaki. Walaubagaimana pun kajian Rosli (1996) mengenai faktor tekanan kerja dan kesan tekanan ke atas 123 orang kakitangan kaunter di Jabatan Pendaftaran Negara mendapati punca tekanan tiada hubungan dengan jantina dan taraf perkahwinan.

Begitu juga dengan kajian oleh Asmawati \& Siva (2002), tekanan kerja di kalangan pensyarah, dimana satu perbandingan di antara university awam dan university swasta. Soal selidik The University Administrative Concerns (Rasch 1986 dipetik dalam Kamarudin 2013) telah ditadbir kepada 120 orang 
pensyarah melalui edaran tangan dan mel elektronik. Keputusan kajian menunjukkan bahawa pensyarah universiti awam mengalami tekanan kerja yang lebih tinggi berbanding dengan pensyarah universiti swasta. Selain daripada itu keputusan menunjukkan terdapat perbezaan yang signifikan tekanan kerja antara pensyarah universiti awam dengan pensyarah universiti swasta berdasarkan subskala peranan dan konflik sosial. Manakala dari segi subskala tugasan dan penyelesaian knflik tidak terdapat perbezaan antara pensyarah di kedua-dua jenis universiti.

Lazarus dan Folkman (1984) telah mengutarakan penilaian kognitif sebagai proses untuk meletakkan tahap tekanan dan mengaitkan tekanan dengan makna yang ada pada kesihatan kendiri. Sebagai contoh seseorang pekerja yang akan menduduki peperiksaan perkhidmatan akan sentiasa berada di dalam keadaan tertekan jika mereka tidak bersiap sedia lebih awal untuk menghadapi peperiksaan. Pandangan perspektif kognitif sentiasa mengaitkan kognitif dan menolak pengalaman lampau sebagai faktor penting penyebab tekanan dan ketidakselesaan di kalangan pekerja. Menurut Kamus Dewan (2007) pula tekanan didefinasikan sebagai keadaan resah, cemas, tegang dan sebagainya yang diakibatkan oleh tekanan mental atau fizikal. Dengan kata lain, tekanan pekerja adalah melibatkan tindak balas fizikal terhadap suatu peristiwa yang boleh menyebabkan ketidakseimbangan berlaku di dalam kehidupan. Tekanan didefinasikan sebagai peristiwa yang menegang atau melebihi keupayaan individu untuk berdaya tindak terhadapnya. Oleh yang demikian, tekanan adalah suatu tindak balas seseorang individu terhadap suatu keadaan dan suasana yang memerlukan penyesuaian daripada segi sistem tubuh badan ataupun pemikiran.

\section{Kajian Luar Negara}

Martin \& Tom (2004), dalam kajiannya untuk melihat tekanan di kalangan pekerja profesional di dalam bidang pembinaan. Kajian memfokuskan kepada sama ada wujud perbezaan tekanan dan punca tekanan di kalangan pekerja lelaki dan wanita di dalam bidang pembinaan dengan menggunakan alat ujian Occupational Stress Indicator (OSI). Hasil kajian menunjukkan pekerja lelaki mengalami tekanan yang lebih tinggi berbanding pekerja perempuan. Kajian juga menunjukkan walaupun terdapat persamaan punca tekanan di antara pekerja lelaki dan perempuan namun terdapat juga perbezaannya. Sebagai contoh pekerja lelaki menganggap keadaan seperti berani mengambil risiko, kesan-kesan dari kesilapan yang dilakukan, pertindihan tugas dan perkembangan kerjaya sebagai punca tekanan. Manakala bagi pekerja wanita pula keadaan seperti peluang untuk perkembangan diri, kadar gaji, perlu berfikir idea-idea baru dan terpaksa bekerja di luar daerah merupakan punca tekanan yang tinggi.

Manakala dalam kajian Cooper dan Marshall (1978) dipetik dalam Haryati (2013) telah mengenal pasti 40 faktor berkait yang dikelompokkan kepada tujuh kategori punca tekanan kerja; (1) faktor instrinsik dalam pekerjaan termasuklah persekitaran kerja seperti permintaan terhadap tenaga fizikal, tugasan yang berulang-ulang dan organisasi, yang dikonsepsualkan sebagai kekaburan peranan, konflik peranan, tanggungjawab terhadap orang lain, kurang rasa tanggungjawab, kurang sokongan daripada pihak pengurusan, kurang penglibatan dalam proses membuat keputusan dan memenuhi perubahan teknologi yang pesat; (3) hubungan di tempat kerja; (4) perkembangan kerjaya; (5) struktur dan iklim organisasi; (6) punca tekanan kerja di luar organisai seperti masalah keluarga, krisis hidup, masalah kewangan dan konflik di tempat kerja dan tuntutan keluarga; dan (7) ciri-ciri individu, fokus khusus kepada perbezaan personaliti di antara individu yang mengalami tekanan yang rendah atau tinggi dan hubungan di antara tingkahlaku Jenis A dan penyakit jantung koronari.

Tekanan kerja di kalangan pekerja kilang Cina dengan menggunakan OSI versi 2 juga telah dijalankan oleh Siu, Donald dan Cooper (1996) terhadap 340 subjek mendapati peratusan yang tinggi di kalangan subjek mempersepsi tekanan kerja yang tinggi. Subskala "faktor instrinsik dalam pekerjaan" adalah punca tekanan yang utama, dan strategi daya tindak berbentuk "kawalan" merupakan strategi yang paling kerap digunakan. Faktor persekitaran merupakan faktor utama yang meramalkan kepuasan kerja, kesihatan mental dan fizikal. Faktor hubungan di antara kepuasan kerja, kesejahteraan mental dan fizikal di kalangan pekerja Cina didapati menyokong dapatan kajian barat.

Rees \& Cooper (1992) turut menjalankan kajian tentang tekanan kerja dalam kalangan 1176 pekerja dari pelbagai jenis pekerjaan di sebuah institusi kesihatan di United Kingdom. Kajian membandingkan 
kumpulan pekerja bukan bidang kesihatan ini mendapati tekanan kerja yang tinggi dialami oleh semua kumpulan pekerja tetapi skor yang rendah bagi tingkah laku Jenis A dan ini menyebabkan kecenderungan individu menggunakan strategi daya tindak dengan lebih kerap dalam mengendalikan tekanan. Tambahan pula, subjek didapati lebih bersifat lokus kawalan luaran dan melaporkan kesihatan mental dan fizikal yang tinggi dan kepuasan kerja yang rendah. Menurut Cooper dan Roberston (1987) semakin besar sesebuah organisasi, semakin tinggi punca tekanan yang dihadapi. Tekanan kerja merupakan reaksi negatif manusia terhadap rangsangan daripada sosial, suasana pekerjaan, ganjaran yang tidak mencukupi, gaya hidup yang terlalu mendesak dan sebagainya. Tekanan kerja juga akan mempengaruhi fizikal dan secara tidak langsung menyebabkan ketidakseimbangan keupayaan pekerja di dalam sesebuah organisasi (Mohd Fikri, 2003).

\section{Tekanan}

Tekanan atau stress, berasal daripada perkataan Greek iaitu Stringere yang bermaksud ketat atau tegang (Cox, 1978). Manakala menurut tokoh yang dianggap sebagai pelopor dalam kajian mengenai tekanan iaitu Hans Seyle (1976) telah mendefinisikan 'tekanan' sebagai gerak balas fizikal badan terhadap permintaan sama ada permintaan positif atau negatif. Apabila terdapat permintaan, maka terdapat reaksi daripada badan.

Menurut Rohani \& Nor Eda, (2001) tekanan merupakan sesuatu perkara yang normal dan penting dalam kehidupan. Tekanan boleh menimbulkan keadaan yang baik dan sebaliknya. Tekanan yang menyebabkan keadaan buruk adalah apabila tekanan menganggu aspek psikologi seseorang. Tekanan didefinisikan sebagai tekanan pada emosi proses pemikiran dan keadaan fizikal seseorang. Apabila tekanan yang dihadapi terlalu tinggi, ianya akan menyebabkan gangguan kepada kebolehan seseorang itu berinterkasi dengan persekitaran. Tekanan yang tinggi juga dikaitkan dengan kebimbangan kronik, mudah marah, sukar untuk menenangkan diri, tidak boleh diajak berunding dan bagi sesetengah pihak akan mengambil alkohol dan dadah yang berlebihan.

Manakala Maria (2011) mengatakan tekanan juga boleh didefinisikan sebagai tindak balas emosi yang tidak spesifik terhadap desakan sama ada yang sebenar atau yang diimaginasikan. Ianya merupakan satu fenomena semula jadi yang tidak boleh dielakkan sekiranya seseorang itu membuat kerja-kerja profesional. Tekanan merupakan normal dalam kehidupan yang sentiasa dipenuhi dengan kesibukan. Setiap orang akan mengalami tekanan (stress) dalam kehidupan seharian mereka. Tekanan (stress) yang berterusan dan keterlaluan menganggu kesihatan mental mahupun kesihatan fizikal. Azmi (2005) pula menyatakan bahawa terdapat beberapa keadaan yang membawa kepada tekanan kerja. Keadaan ini dipanggil 'stressor' atau penyebab. Antara penyebab tersebut ialah bebanan tugas, tekanan masa, kualiti penyeliaan yang lemah, ketidaksesuaian pihak atasan berbanding dengan tanggungjaawab sebenar, konflik peranan, nilai-nilai yang berbeza di antara organisasi dan pekerja serta kekecewaan. Tekanan yang wujud daripada beban kerja mental (mental workload) merupakan kesan terlalu banyak beban kerja atau terlalu sedikit beban kerja serta faktor kecekapan melakukan sesuatu tugas. Keempat, akibat daripada kerja lebih masa. Kelima, faktor tanggungjawab kerja dan akhir sekali ialah cabaran tugas tersebut. Dengan ini dapat disimpulkan bahawa tekanan kerja adalah hasil yang disebabkan oleh faktor-faktor yang telah dinyatakan di atas.

\section{Tekanan Kerja}

Brief, Schuler \& Van (1981) menyatakan tekanan kerja merupakan tindak balas individu terhadap perkara-perkara yang berlaku dalam persekitaran kerja, di mana ianya mengancam individu tersebut. Individu tersebut tidak dapat menyesuaikan diri dengan keadaan persekitaran kerja. Seterusnya Brief et. al (1981) menganggap tekanan sebagai keadaan yang timbul daripada interaksi antara individu dengan kerjaya dan dicirikan oleh pemboleh ubah dalam individu itu yang memaksanya mnyeleweng daripada berfungsi secara normal atau biasa. Definisi ini dapat difahami dengan baik apabila mengambil kira bahawa tubuh badan dan fikiran berada dalam keadaan yang seimbang pada permulaan sesuatu pengalaman kerja, tetapi akibat daripada kejadian yang berkaitan dengan kerja, keseimbangan seseorang itu terganggu. Dalam percubaan untuk pulih daripada gangguan atau ketidakseimbangan, seseorang itu akan berfungsi secara berlainan daripada biasa. Salvendy \& Smith (1988) menyatakan 
konsep tekanan kerja boleh dibicarakan melalui beberapa sudut. Pertama, tekanan yang terhasil daripada keadaan tempat kerja. Contohnya keadaan bising dan pengudaraan yang kurang baik. Ini akan mengurangkan motivasi kerja seseorang. Kedua, tekanan yang terhasil daripada dua faktor organisasi iaitu penglibatn dalam tugas dan sokongan organisasi.

Tekanan kerja merupakan satu keadaan yang timbul akibat interaksi manusia dengan kerja mereka. Ianya dicirikan sebagai perubahan-perubahan dalam diri manusia yang menyebabkan mereka berubah daripada berfungsi secara normal kepada tidak normal (Rohany \& Eda, 2001). Rohany \& Eda (2001) mendefinisikan tekanan kerja sebagai persekitaran kerja yang menghasilkan ancaman kepada individu. Ancaman berlaku apabila individu tidak berupaya untuk memenuhi tuntutan persekitaran kerja. Dapat dirumuskan di sini bahawa kesemua definisi tersebut mengaitkan tekanan kerja wujud dan pelbagai faktor sama ada persekitaran tempat kerja, dari sudut psikologi, individu itu sendiri dan lain-lain.

\section{Faktor Tekanan}

Menurut Cooper dan Roberston (1987) semakin besar sesebuah organisasi, semakin tinggi punca tekanan yang dihadapi. Tekanan kerja merupakan reaksi negatif manusia terhadap rangsangan daripada sosial, suasana pekerjaan, ganjaran yang tidak mencukupi, gaya hidup yang terlalu mendesak dan sebagainya. Tekanan kerja juga akan mempengaruhi fizikal dan secara tidak langsung menyebabkan ketidakseimbangan keupayaan pekerja di dalam sesebuah organisasi (Mohd Fikri, 2003). Terdapat pelbagai punca terjadinya tekanan kerja di kalangan pekerja di antaranya adalah masalah kewangan dan kekurangan pekerja (Mohamad Puzi dan Noor Hashim, 2001 dipetik dalam Rosidah Ramli, 2016). Bukan setakat itu sahaja malah faktor beban kerja yang tidak tertanggung, kematian dan konflik juga merupakan antara penyumbang kepada tekanan kerja (Emilia Zainal Abidin dan Noor Hassim Ismail, 2006). Keadaan ini jelas menunjukkan bahawa tahap tekanan yang dihadapi oleh pekerja adalah berbeza mengikut jenis pekerjaan dan tugasan yang dilakukan. Tekanan kerja yang keterlaluan akan mengakibatkan pekerja menjadi tegang, bimbang dan takut dan secara tidak langsung mengakibatkan terjadinya tindak balas psikologi dan perubahan fisiologi (Ishak, 2004 dipetik dalam Rosidah, 2016).

Kebanyakan pekerja tidak akan mengalami tekanan kerja yang berpunca daripada situasi kecemasan dan ancaman kerja yang bersifat fizikal. Tetapi tekanan kerja yang dihadapi oleh pekerja adalah bersifat psikologi dan emosional (Mahmood Nazar, 2014 dipetik dalam Rosidah Ramli, 2016). Tekanan kerja menyebabkan adrenalin dibebaskan dari kelenjar adrenal dan mempercepatkan fungsi badan. Keadaan ini menyebabkan perubahan fisiologi seperti peningkatan tekanan darah, degupan jantung meningkat, dan lebih banyak gula akan dibebaskan ke dalam salur darah. Pertambahan peredaran darah akan menyebabkan pertambahan tenaga yang secara tidak langsung menyebabkan perubahan fisiologi dan psikologi keatas pekerja. Perubahan fisiologi pula kebiasaannya akan ditonjolkan dalam bentuk gejala. Sebenarnya terdapat pelbagai gejala yang dirasai oleh pekerja akibat tekanan kerja, antaranya adalah pekerja akan kelihatan letih dan pencapaian peribadi merosot (Ayub, dan Baco, 2008). Bukan setakat itu sahaja malah gejala seperti ketegangan, keresahan, kemurungan, masalah gastrousus, serta gejala fizikal yang lain turut akan dialami sekiranya pekerja berdepan dengan tekanan kerja (Md Zain, 1999).

Pada peringkat awal tekanan kerja berada pada tahap yang rendah, namun ianya akan bertambah sekiranya faktor tekanan kerja itu semakin bertambah. Setiap kali berlaku tekanan baru kepada pekerja maka ianya secara tidak langsung akan menambahkan tekanan sedia ada dalam diri pekerja itu sendiri dan secara tidak langsung pekerja terpaksa menggunakan tenaga simpanan untuk mengatasi tekanan yang dihadapi. Jika keadaan ini berterusan atau bertambah maka perubahan fisiologi, keletihan emosi dan depolarisasi akan berlaku dan akhirnya membawa kepada psikosomatik iaitu berlaku kerosakan tisu dan organ serta kesakitan fisiologi (Lee dan Ashforth, 1996 dipetik dalam Rosidah, 2016). Perkembangan globalisasi sesebuah organisasi mempunyai pelbagai cabaran dalam mempertahankan kelebihan daya saing organisasi. Kepelbagaian cetusan inovasi harus dicungkil dan harus diketengahkan demi mempertahankan kredibiliti dan kualiti sesebuah organisasi. Namun dalam mengejar kemegahan ini, ada ketikanya organisasi mula leka dan terlupa terhadap kepentingan sumber manusia. Kelekaan ini telah menyumbang kepada kepelbagaian masalah antaranya adalah tekanan 
kerja. Fenomena tekanan kerja mula dilihat sebagai sejenis virus yang akan merosakkan sesebuah organisasi.

Rohany \& Fatimah (2006) menyatakan apabila pekerja mengalami konflik di tempat kerja, hal ini boleh mempengaruhi mereka di rumah. Perkara yang sebaliknya juga akan berlaku. Oleh itu, pekerja yang mengalami masalah di rumah seperti masalah keluarga, krisis hidup, masalah kewangan, kematian atau masalah perhubungan berkemungkinan tidak dapat melaksanakan tugas dengan baik di pejabat. Struktur dan iklim organisasi mungkin menghadkan otonomi pekerja. Pekerja mungkin merasa mereka tidak banyak kawalan ke atas tugas mereka. Mereka mungkin merasakan tugas mereka sangat menjemukan dan tidak mencabar dan ini boleh menyumbang kepada ketidakpuasan bekerja, merasa sakit hati, merasa rendah diri dan kehilangan identity diri. Majikan boleh mengurangkan masalah ini dengan meningkatkan keterlibatan pekerja dalam membuat keputusan dan mengalakkan kerja secara berkumpulan untuk mengatasi kawalan pekerja. (Sapora Sipon. n.d). Zainah \& Hamdan, (2002) menyatakan peranan dalam pengurusan dikonsepsualkan sebagai kekaburan peranan, konflik peranan, tanggungjawab terhadap orang lain, kurang rasa tanggungjawab, kurang sokongan daripada pihak pengurusan, kurang penglibatan dalam proses membuat keputusan dan memenuhi perubahan terknologi yang pesat. Haprizar, Norulkamar \& Siti Aishah, (2005) menyatakan perkembangan kerjaya yang tidak menentu merujuk kepada kurang atau tiada peluang kerja serta kurang jaminan kerja. Cox et. al. (1998) menjelaskan perhubungan dan sokongan sosial boleh dipertingkatkan melalui aktiviti sosial dalam usaha mengurangkan stress di tempat kerja. Perhubungan yang sukar dengan rakan sekerja atau pihak pentadbir di tempat kerja boleh menjadi punca stress kepada pekerja. Rakan sekerja mungkin tidak mempunyai kemahiran dalam perhubungan dan berkomunikasi dan ini boleh nmenyebabkan mereka melahirkan sikap seperti agresif, tidak mahu membantu dan sebagainya yang memberi kesan stress kepada pekerja. Perhubungan juga boleh menjadi negative akibat daripada politik di pejabat, persaingan dan gangguan tempat kerja. Menurut Zainah \& Hamdan, (2002) faktor intrinsik dalam pekerjaan termasuklah persekitaran kerja seperti permintaan terhadap tenaga fizikal, tugasan yang berulang-ulang dan lebihan kerja secara kuantitatif dan kualitatif. (Haprizar, Norulkamar \& Siti Aishah, 2005) pula menyatakan elemen intrinsik kerja merangkumi kebosanan, keadaan tempat kerja yang tidak terurus, tekanan masa dan masalah teknikal.

\section{Metodologi}

Kajian tinjauan ini menggunakan kaedah kuantitatif kerana ianya sesuai digunakan untuk mendapatkan maklumat yang banyak mengenai faktor tekanan kerja berdasarkan demografi dalam masa yang singkat. Kajian ini menggunakan soal selidik sebagai instrumen kajian. Populasi kajian adalah terdiri daripada kakitangan-kakitangan yang berkhidmat di Hospital Kerajaan Sibu, Sarawak. Lokasi kajian yang dipilih adalah di Sibu, Sarawak. Hal ini kerana, Hospital Kerajaan Sibu merupakan sebuah hospital kerajaan yang terletak di Sarawak, Malaysia. Hospital Kerajaan Sibu merupakan hospital kedua terbesar di negeri Sarawak, Malaysia. Ianya merupakan hospital utama dan rujukan bagi Wilayah Tengah di Sarawak, Malaysia. Selain itu, Hospital KerajaanSibu juga berkhidmat sebagai hospital rujukan bagi Hospital Daerah sepanjang lembah Rejang dan juga di Mukah, Saratok dan Bintulu. Bahkan juga, Hospital Sibu tidak hanya memenuhi keperluan perubatan penduduk Wilayah Sibu, tetapi juga jagaan tertiari dan pakar bagi Wilayah Bintulu, Wilayah Kapit, Wilayah Mukah dan Wilayah Sarikei.

Populasi bagi penyelidikan ini adalah kakitangan Hospital Kerajaan Sibu, Sarawak. Populasi kakitangan Hospital Sibu adalah sebanyak 2,000 orang yang terdiri daripada beberapa bahagian perkhidmatan. Pertama, iaitu bahagian perkhidmatan klinikal yang terdiri daripada doktor, jururawat, pembantu perubatan, matron dan sebagainya. Kedua, bahagian perkhidmatan sokongan klinikal iaitu pegawai farmasi, pegawai makmal perubatan, pegawai fisioterapi dan sebagainya. Ketiga pula, bahagian perkhidmatan pengurusan iaitu bahagian pengurusan dan pentadbiran serta kewangan dan akaun. Pengkaji telah memilih seramai 322 orang kakitangan hospital sebagai sampel kajian berdasarkan penentuan saiz sampel Krejcie dan Morgan (1970). Sampel dipilih secara rawak mudah. 
Dalam kajian ini, instrumen kajian yang digunakan adalah berbentuk soal selidik yang dibina oleh Cooper, Sloan \& Williams (1988) iaitu Occupational Stress Indicator (OSI). Penggunaan OSI dalam kajian ini adalah amat bersesuaian dengan tujuan kajian mengukur tekanan kerja dan faktor-faktor tekanan dalam pekerjaan dalam kalangan kakitangan Hospital Sibu, Sarawak. Manakala, instrumen kajian seterusnya adalah berbentuk soal selidik iaitu adaptasi daripada kajian oleh Mohammad Abdillah Royo dan Woo Sew Fun, iaitu kajian yang bertajuk Faktor-Faktor Yang Mendorong Tekanan Kerja (Stress) di Kalangan Guru-Guru SJK(C).

Instrumen utama yang terlibat dalam proses pengumpulan data bagi kajian yang akan dijalankan ini adalah borang soal selidik. Set soal selidik ini dibahagikan kepada tiga (3) bahagian. Bahagian A adalah untuk mengetahui maklumat latar belakang demografi responden. Bahagian B pula, untuk mengetahui faktor-faktor tekanan kerja. Manakala, bahagian $\mathrm{C}$ adalah untuk mengetahui tahap tekanan kerja. Kandungan borang soal selidik bagi bahagian A, bahagian B dan bahagian C adalah seperti yang terdapat pada Jadual 1 dibawah. Manakala Jadual 2 adalah skala yang digunakan dalam kajian bagi bahagian $\mathrm{B}$ dan $\mathrm{C}$.

Jadual 1: Kandungan Borang Soal Selidik

\begin{tabular}{clcc}
\hline Bahagian & \multicolumn{1}{c}{ Item } & Bilangan Item & Pembolehubah \\
\hline A & Jantina & 1 & \\
& Umur & 1 & Terdahulu \\
& Status perkahwinan & 1 & \\
Tempoh perkhidmatan & 1 & \\
& Waktu Bekerja & 1 & \\
B & Faktor halangan kerja rumah dan & 12 & \multirow{2}{*}{ Tidak Bersandar } \\
& kerja & 11 & \\
& Faktor struktur dan iklim organisasi & 11 & \multirow{2}{*}{ Bersandar } \\
& Faktor peranan pengurusan & 9 & \\
& Faktor kerjaya dan pencapaian & 9 & \\
& Faktor hubungan di tempat kerja & 9 & \\
& Faktor intrinsik dalam pekerjaan & 20 & \\
& Tahap tekanan kerja $\quad$ Jumlah & 86 & \\
& & &
\end{tabular}

Jadual 2: Skala Likert bagi Bahagian B dan C

\begin{tabular}{cc}
\hline Skala & Interpretasi Tahap \\
\hline 1 & Sangat Tidak Setuju \\
2 & Tidak Setuju \\
3 & Neutral \\
4 & Setuju \\
5 & Sangat Setuju \\
\hline
\end{tabular}

Jadual 3 di bawah menunjukan Penentuan Tahap bagi Skor Mean yang digunakan bagi menentukan tahap dalam kajian ini.

Jadual 3: Penentuan Tahap bagi Skor Mean

\begin{tabular}{lccccc}
\hline Skala Likert & $\mathbf{1}$ & $\mathbf{2}$ & $\mathbf{3}$ & $\mathbf{4}$ & $\mathbf{5}$ \\
\hline Penerangan & $\begin{array}{c}\text { Sanagt } \\
\text { Tidak } \\
\text { Setuju }\end{array}$ & $\begin{array}{c}\text { Tidak } \\
\text { Setuju }\end{array}$ & Neutral & Setuju & $\begin{array}{c}\text { Sangat } \\
\text { Setuju }\end{array}$ \\
\hline $\begin{array}{l}\text { Skor } \text { Mean } \\
\text { Tahap }\end{array}$ & $\begin{array}{c}1.00-2.99 \\
\text { Rendah }\end{array}$ & $\begin{array}{c}3.00 \\
\text { Sederhana }\end{array}$ & $\begin{array}{c}\text { 3.01-5.00 } \\
\text { Tinggi }\end{array}$ \\
\hline
\end{tabular}


Jadual 4 di bawah menunjukan Kekuatan Hubungan Kolerasi yang digunakan di dalam kajian ini.

Jadual 4: Kekuatan Hubungan Korelasi

\begin{tabular}{cl} 
Nilai Korelasi (r) & \multicolumn{1}{c}{ Kekuatan Hubungan } \\
\hline .90 to \pm 1.0 & Korelasi positif/negatif yang tinggi \\
\pm .70 to \pm .90 & Korelasi positif/negatif yang tinggi \\
\pm .50 to \pm .70 & Korelasi positif/negatif sederhana \\
\pm .30 to \pm .50 & Korelasi positif/negatif rendah \\
\pm .00 to \pm .30 & Tidak ada korelasi \\
\hline
\end{tabular}

Berdasarkan Jadual 5, skor Cronbach's Alpha untuk faktor halangan rumah dan kerja ialah .738, struktur dan iklim organisasi ialah .732, peranan dan pengurusan ialah .766, kerjaya dan pencapaian ialah .716, hubungan di tempat kerja ialah .753 dan faktor intrinsik dalam pekerjaaan ialah .696 dan semuanya 0.6 ke atas dan boleh diterima. Nilai Cronbach Alpha yang melebihi 0.60 sering kali diguna pakai sebagai indeks kebolehpercayaan sesuatu instrument (Mohd Majid 1990; Pallant 2001; Siti Rahayah 2003).

Jadual 5: Kebolehpercayaan Sebenar

\begin{tabular}{clc} 
No. & \multicolumn{1}{c}{ Pemboleh Ubah Tidak Bersandar } & Cronbach's Alpha \\
\hline 1. & Halangan Rumah dan Kerja & .738 \\
2. & Struktur dan Iklim Organisasi & .732 \\
3. & Peranan Pengurusan & .766 \\
4. & Kerjaya dan Pencapaian & .716 \\
5. & Hubungan di Tempat Kerja & .753 \\
6. & Faktor Intrinsik Dalam Pekerjaan & .696 \\
\hline
\end{tabular}

\section{Dapatan Kajian}

\section{Analisis Latar Belakang Demografi}

Jadual 6 menunjukan taburan jantina kakitangan kerajaan iaitu Hospital Sibu, Sarawak. Bilangan pekerja lelaki adalah 134 (41.6\%) orang manakala 188 (58.4\%) orang pekerja perempuan.

Jadual 6: Taburan Jantina Responden

\begin{tabular}{|c|c|c|}
\hline Jantina & Bilangan & Peratus (\%) \\
\hline Lelaki & 134 & 41.6 \\
\hline Perempuan & 188 & 58.4 \\
\hline Jumlah & 322 & 100 \\
\hline
\end{tabular}

Jadual 7, 223 (69.3\%) orang responden daripada golongan belia iaitu berumur 15 - 40 tahun. Manakala $99(30.7 \%)$ orang responden daripada golongan pertengahan iaitu berumur $45-55$ tahun.

Jadual 7: Taburan Umur Responden

\begin{tabular}{lcc}
\hline \multicolumn{1}{c}{ Umur (Golongan) } & Bilangan & Peratus (\%) \\
\hline $15-40$ tahun (Belia) & 223 & 69.3 \\
$41-55$ tahun (Pertengahan Umur) & 99 & 30.7 \\
\hline Jumlah & 322 & 100 \\
\hline
\end{tabular}


DOI: https://doi.org/10.47405/mjssh.v5i10.522

Jadual 8, 76 (23.6\%) orang responden daripada subjek adalah berstatus bujang, manakala 244 (75.8\%) orang responden terdiri daripada individu yang telah berkahwin dan bercerai sebanyak $0(0 \%)$.

Jadual 8: Taburan Status Perkahwinan Responden

\begin{tabular}{lcc}
\multicolumn{1}{c}{ Status Perkahwinan } & Bilangan & Peratus (\%) \\
\hline Bujang & 76 & 23.6 \\
Berkahwin & 244 & 75.8 \\
Bercerai & 0 & 0 \\
\hline \multicolumn{1}{c}{ Jumlah } & 322 & 100
\end{tabular}

Jadual 9, $55(17.1 \%)$ orang responden berkhidmat kurang daripada 5 tahun, manakala $94(29.2 \%)$ orang responden yang berkhidmat di antara 6 - 10 tahun dan $173(53.7 \%)$ orang responden terdiri daripada individu yang berkhidmat lebih daripada 10 tahun.

Jadual 9: Taburan Tempoh Perkhidmatan Responden

\begin{tabular}{lcc}
\hline \multicolumn{1}{c}{ Tempoh Perkhidmatan } & Bilangan & Peratus (\%) \\
\hline 5 tahun ke bawah & 55 & 17.1 \\
$6-10$ tahun & 94 & 29.2 \\
10 tahun ke atas & 173 & 53.7 \\
\hline Jumlah & 322 & 100 \\
\hline
\end{tabular}

Jadual 10, $197(61.2 \%)$ orang responden daripada keseluruhan subjek bekerja pada waktu pejabat, manakala 125 (38.8\%) orang responden bekerja pada waktu syif.

Jadual 10: Taburan Waktu Bekerja Responden

\begin{tabular}{lcc}
\multicolumn{1}{c}{ Waktu Bekerja } & Bilangan & Peratus (\%) \\
\hline Waktu Pejabat & 197 & 61.2 \\
Syif & 125 & 38.8 \\
\hline Jumlah & 322 & 100 \\
\hline
\end{tabular}

\section{Analisis Faktor Tekanan Kerja}

Berdasarkan Jadual 11, terdapat dua faktor tekanan kerja yang mencatatkan skor mean tinggi oleh kakitangan Hospital Kerajaan Sibu, Sarawak iaitu faktor struktur dan iklim organisasi dengan skor mean 3.1016 dan faktor intrinsik dalam pekerjaan dengan skor mean 3.0707. Manakala faktor tekanan lain seperti faktor kerjaya dan pencapaian (mean $=2.9579)$, faktor hubungan di tempat kerja (mean $=$ $2.8392)$, faktor halangan rumah dan kerja $($ mean $=2.6667)$ dan faktor peranan pengurusan ( mean $=$ 2.6556) mencatatkan skor min pada tahap rendah.

\section{Jadual 11: Skor Min Faktor Tekanan}

\begin{tabular}{lc}
\hline \multicolumn{1}{c}{ Pembolehubah Tidak Bersandar } & Mean \\
\hline Struktur dan Iklim Organisasi & 3.1016 \\
Faktor Intrinsik dalam Pekerjaan & 3.0707 \\
Kerjaya dan Pencapaian & 2.9579 \\
Hubungan di Tempat Kerja & 2.8392 \\
Halangan Rumah dan Kerja & 2.6667 \\
Peranan Pengurusan & 2.6556 \\
\hline
\end{tabular}

\section{Analisis Tahap Tekanan Kerja}

Jadual 12 menunjukkan skor min bagi tahap tekanan kerja. Nilai skor min bagi tahap tekanan kerja adalah 3.3262 iaitu pada tahap yang tinggi. 
Jadual 12: Tahap Tekanan Kerja

\begin{tabular}{lc}
\multicolumn{1}{c}{ Pembolehubah Bersandar } & Min \\
\hline Tahap Tekanan Kerja & 3.3262 \\
\hline
\end{tabular}

\section{Analisis Perhubungan antara Faktor Tekanan Kerja dengan Tahap Tekanan Kerja}

Ha Terdapat perhubungan antara faktor struktur dan iklim organisasi dengan tahap tekanan $1.1 \quad$ kerja

Jadual 13 menunjukkan terdapat hubungan yang signifikan sederhana, dengan nilai $r=.577$ pada aras $P$ $=.000,<0.05$. Oleh yang demikian, kajian ini menerima hipotesis alternatif (Ha1.1) dimana didapati struktur dan iklim organisasi mempunyai hubungan yang signifikan dengan tahap tekanan kerja dalam kalangan kakitangan Hospital Kerajaan Sibu, Sarawak.

Jadual 13: Analisis Perhubungan antara Faktor Struktur dan Iklim Organisasi dengan Tahap Tekanan

\begin{tabular}{lccc}
\hline \multicolumn{1}{c}{ Item } & Tahap Tekanan & $\begin{array}{c}\text { Struktur dan Iklim } \\
\text { Organisasi }\end{array}$ \\
\hline Tahap Tekanan & Pearson Correlation & 1 & $.577^{* *}$ \\
Struktur dan Iklim & Sig. $(2-$ Tailed $)$ & & .000 \\
Organisasi & Pearson Correlation & $.577^{* *}$ & 322 \\
& Sig. $(2-$ Tailed $)$ & .000 & 1 \\
& $N$ & 322 & 322 \\
\hline
\end{tabular}

Ha Terdapat perhubungan antara faktor intrinsik dalam pekerjaan dengan tahap tekanan

1.2 kerja

Jadual 14 menunjukkan terdapat hubungan yang signifikan sederhana, dengan nilai $\mathrm{r}=.535$ pada aras $\mathrm{P}$ $=.000,<0.05$. Oleh yang demikian, kajian ini menerima hipotesis alternatif (Ha1.2) dimana didapati faktor intrinsik dalam pekerjaan mempunyai hubungan yang signifikan dengan tahap tekanan kerja dalam kalangan kakitangan Hospital Kerajaan Sibu, Sarawak.

Jadual 14: Analisis Perhubungan antara Faktor Intrinsik dalam Pekerjaan dengan Tahap Tekanan

\begin{tabular}{lccc}
\hline & Item & Tahap Tekanan & $\begin{array}{c}\text { Faktor Intrinsik } \\
\text { Dalam Pekerjaan }\end{array}$ \\
\hline Tahap Tekanan & Pearson Correlation & 1 & $.535^{* *}$ \\
& Sig. $(2-$ Tailed $)$ & & .000 \\
Faktor Intrinsik & $N$ & 322 & 322 \\
Dalam Pekerjaan & Pearson Correlation & $.535^{* *}$ & 1 \\
& Sig. $(2-$ Tailed $)$ & .000 & 322 \\
\hline
\end{tabular}

Ha Terdapat perhubungan antara faktor kerjaya dan pencapaian dengan tahap tekanan 1.3 kerja

Jadual 15 menunjukkan terdapat hubungan yang signifikan sederhana, dengan nilai $r=.559$ pada aras $P$ $=.000,<0.05$. Oleh yang demikian, kajian ini menerima hipotesis alternatif (Ha1.3) dimana didapati 
faktor kerjaya dan pencapaian mempunyai hubungan yang signifikan dengan tahap tekanan kerja dalam kalangan kakitangan Hospital Kerajaan Sibu, Sarawak.

Jadual 15: Analisis Perhubungan antara Faktor Kerjaya dan Pencapaian dengan Tahap Tekanan

\begin{tabular}{lccc}
\hline \multicolumn{1}{c}{ Item } & Tahap Tekanan & $\begin{array}{c}\text { Faktor Kerjaya dan } \\
\text { Pencapaian }\end{array}$ \\
\hline Tahap Tekanan & Pearson Correlation & 1 & $.559^{* *}$ \\
& Sig. $(2-$ Tailed $)$ & & .000 \\
Faktor Kerjaya dan & Pearson Correlation & $.559^{* *}$ & 322 \\
Pencapaian & Sig. $(2-$ Tailed $)$ & .000 & 1 \\
& $N$ & 322 & 322 \\
\hline
\end{tabular}

Ha Terdapat perhubungan antara faktor hubungan di tempat kerja dengan tahap tekanan

1.4 kerja

Jadual 16 menunjukkan terdapat hubungan yang signifikan sederhana, dengan nilai $r=.604$ pada aras $P$ $=.000,<0.05$. Oleh yang demikian, kajian ini menerima hipotesis alternatif (Ha1.4) dimana didapati faktor hubungan di tempat kerja mempunyai hubungan yang signifikan dengan tahap tekanan kerja dalam kalangan kakitangan Hospital Kerajaan Sibu, Sarawak.

Jadual 16: Analisis Perhubungan antara Faktor Hubungan di Tempat Kerja dengan Tahap Tekanan

\begin{tabular}{lccc}
\hline \multicolumn{1}{c}{ Item } & Tahap Tekanan & $\begin{array}{c}\text { Faktor Hubungan di } \\
\text { Tempat Kerja }\end{array}$ \\
\hline Tahap Tekanan & Pearson Correlation & 1 & $.604^{* *}$ \\
& Sig. $(2-$ Tailed $)$ & & .000 \\
Faktor Hubungan di & $N$ & 322 & 322 \\
Tempat Kerja & Pearson Correlation & $.604^{* *}$ & 1 \\
& Sig. $(2-$ Tailed $)$ & .000 & 322 \\
\hline
\end{tabular}

Ha Terdapat perhubungan antara faktor halangan rumah dan kerja dengan tahap tekanan 1.5 kerja

Jadual 17 menunjukkan terdapat hubungan yang signifikan sederhana, dengan nilai $\mathrm{r}=.585$ pada aras $\mathrm{P}$ $=.000,<0.05$. Oleh yang demikian, kajian ini menerima hipotesis alternatif (Ha1.5) dimana didapati faktor halangan rumah dan kerja mempunyai hubungan yang signifikan dengan tahap tekanan kerja dalam kalangan kakitangan Hospital Kerajaan Sibu, Sarawak.

Jadual 17: Analisis Perhubungan antara Faktor Halangan Rumah dan Kerja dengan Tahap Tekanan

\begin{tabular}{lccc}
\hline & Item & Tahap Tekanan & $\begin{array}{c}\text { Faktor Halangan } \\
\text { Rumah dan Kerja }\end{array}$ \\
\hline Tahap Tekanan & Pearson Correlation & 1 & $.585^{* *}$ \\
& Sig. $(2-$ Tailed $)$ & & .000 \\
Faktor Halangan & $N$ & 322 & 322 \\
Rumah dan Kerja & Pearson Correlation & $.585^{* *}$ & 1 \\
& Sig. $(2-$ Tailed $)$ & .000 & 322 \\
\hline
\end{tabular}


Ha Terdapat perhubungan antara faktor peranan pengurusan dengan tahap tekanan kerja

1.6

Jadual 18 menunjukkan terdapat hubungan yang signifikan sederhana, dengan nilai $\mathrm{r}=.624$ pada aras $\mathrm{P}$ $=.000,<0.05$. Oleh yang demikian, kajian ini menerima hipotesis alternatif (Ha1.6) dimana didapati faktor peranan pengurusan mempunyai hubungan yang signifikan dengan tahap tekanan kerja dalam kalangan kakitangan Hospital Kerajaan Sibu, Sarawak.

Jadual 18: Analisis Perhubungan antara Faktor Peranan Pengurusan dengan Tahap Tekanan

\begin{tabular}{lccc}
\hline & Item & Tahap Tekanan & $\begin{array}{c}\text { Faktor Peranan } \\
\text { Pengurusan }\end{array}$ \\
\hline \multirow{3}{*}{ Tahap Tekanan } & Pearson Correlation & 1 & $.624^{* *}$ \\
& Sig. $(2-$ Tailed $)$ & & .000 \\
Faktor Peranan & $N$ & 322 & 322 \\
Pengurusan & Pearson Correlation & $.624^{* *}$ & 1 \\
& Sig. $(2-$ Tailed $)$ & .000 & 322 \\
\hline
\end{tabular}

\section{Analisis Perbezaan Tahap Tekanan Kerja dengan Latar Belakang Demografi}

Jadual 19 dan 20 menunjukkan tidak terdapat perbezaan yang signifikan bagi jantina $\mathrm{F}(1,320)=.063$; $\mathrm{P}=.802,>0.05$. Manakala keputusan yang perbezaan signifikan bagi golongan umur $\mathrm{F}(3,318)=2.507$; $\mathrm{P}=.020,<0.05$, status perkahwinan $\mathrm{F}(2,319)=1.725 ; \mathrm{P}=.018,<0.05$, tempoh perkhidmatan $\mathrm{F}$ $(2,319)=7.058 ; \mathrm{P}=.001,<0.05$ dan waktu bekerja $\mathrm{F}(1,320)=34.846 ; \mathrm{P}=.000,<0.05$ dalam kalangan kakitangan Hospital Kerajaan Sibu, Sarawak.

Jadual 19: Analisis Perbezaan Tahap Tekanan Kerja dengan Latar Belakang Demografi

\begin{tabular}{lccccc}
\hline Jantina & $d f$ & Sum of Squares & Mean Square & $F$ & Sig. \\
Between Groups & 1 & .038 & .038 & .063 & .802 \\
Within Groups & 320 & 190.928 & .597 & & \\
Total & 321 & 190.966 & & & \\
Kumpulan Umur & $d f$ & Sum of Squares & Mean Square & $F$ & Sig. \\
Between Groups & 3 & 4.413 & 1.471 & 2.507 & .020 \\
Within Groups & 318 & 186.553 & .587 & & \\
Total & 321 & 190.966 & & & \\
Status Perkahwinan & $d f$ & Sum of Squares & Mean Square & $F$ & Sig. \\
Between Groups & 2 & 2.403 & 1.022 & 1.725 & .018 \\
Within Groups & 319 & 188.923 & .592 & & \\
Total & 321 & 190.966 & & & \\
Tempoh Perkhidmatan & $d f$ & Sum of Squares & Mean Square & $F$ & Sig. \\
Between Groups & 2 & 8.092 & 4.046 & 7.058 & .001 \\
Within Groups & 319 & 182.873 & .573 & & \\
Total & 321 & 190.966 & & & \\
Waktu Bekerja & $d f$ & Sum of Squares & Mean Square & $F$ & Sig. \\
Between Groups & 1 & 18.753 & 18.753 & 34.846 & .000 \\
Within Groups & 320 & 172.213 & .538 & & \\
Total & 321 & 190.966 & & & \\
\hline
\end{tabular}

Jadual 20: Analisis Perbezaan Skor Mean Tahap Tekanan Kerja dengan Latar Belakang Demografi

\begin{tabular}{lcc}
\hline Jantina & $\mathrm{N}$ & Mean \\
\hline Lelaki & 134 & 2.3134 \\
Perempuan & 188 & 2.3354 \\
\hline
\end{tabular}



DOI: https://doi.org/10.47405/mjssh.v5i10.522

\begin{tabular}{lcc}
\hline Total & 322 & 2.3262 \\
\hline Kumpulan Umur & $\mathrm{N}$ & Mean \\
\hline $5-40$ tahun (Belia) & 223 & 2.4921 \\
$41-55$ tahun (Pertengahan Umur) & 99 & 2.2430 \\
Total & 322 & 2.3262 \\
\hline Tahap Perkahwinan & $\mathrm{N}$ & Mean \\
\hline Bujang & 78 & 2.6691 \\
Berkahwin & 244 & 2.2828 \\
Total & 322 & 2.3262 \\
\hline Tempoh Perkhidmatan & $\mathrm{N}$ & Mean \\
\hline 5 tahun ke bawah & 55 & 2.2091 \\
$6-10$ tahun & 94 & 2.5729 \\
10 tahun ke atas & 173 & 2.2295 \\
Total & 322 & 2.3262 \\
\hline Waktu Bekerja & $\mathrm{N}$ & Mean \\
\hline Waktu Pejabat & 197 & 2.1340 \\
Syif & 125 & 2.6292 \\
Total & 322 & 2.3262 \\
\hline
\end{tabular}

\section{Analisis Perbezaan Faktor Tekanan Kerja dengan Latar Belakang Demografi}

\section{Analisis Perbezaan Faktor Tekanan Kerja dengan Jantina}

Jadual 21 dan 22 menunjukkan tidak terdapat perbezaan yang signifikan bagi halangan kerja dan rumah $\mathrm{F}(1,320)=.429 ; \mathrm{P}=.513,>0.05$ struktur iklim dan organisasi $\mathrm{F}(1,320)=.393 ; \mathrm{P}=.531,>0.05$, peranan pengurusan $\mathrm{F}(1,320)=4.727 ; \mathrm{P}=.080,>0.05$, kerjaya dan pencapaian $\mathrm{F}(1,320)=2.926 ; \mathrm{P}=$ $.088,>0.05$, hubungan di tempat kerja $\mathrm{F}(1,320)=2.059 ; \mathrm{P}=.152,>0.05$, faktor intrinsik dalam pekerjaan $\mathrm{F}(1,320)=.114 ; \mathrm{P}=.732,>0.05$ dengan jantina dalam kalangan kakitangan Hospital Kerajaan Sibu Sarawak.

Jadual 21: Analisis Perbezaan Faktor Tekanan Kerja dengan Jantina

\begin{tabular}{lccccc}
\hline Halangan Kerja dan Rumah & $d f$ & Sum of Squares & Mean Square & $F$ & Sig. \\
Between Groups & 1 & .269 & .269 & .429 & .513 \\
Within Groups & 320 & 200.148 & .625 & & \\
Total & 321 & 200.417 & & & \\
Struktur Iklim dan Organisasi & $d f$ & Sum of Squares & Mean Square & $F$ & Sig. \\
Between Groups & 1 & .222 & .222 & .393 & .531 \\
Within Groups & 320 & 180.452 & .564 & & \\
Total & 321 & 180.674 & & & \\
Peranan Pengurusan & $d f$ & Sum of Squares & Mean Square & $F$ & Sig. \\
Between Groups & 1 & 2.243 & 2.243 & 4.727 & .080 \\
Within Groups & 320 & 151.821 & .474 & & \\
Total & 321 & 154.063 & & & \\
Kerjaya dan Pencapaian & $d f$ & Sum of Squares & Mean Square & $F$ & Sig. \\
Between Groups & 1 & 1.571 & 1.571 & 2.926 & .088 \\
Within Groups & 320 & 171.785 & .537 & & \\
Total & 321 & 173.355 & & & \\
Hubungan di Tempat Kerja & $d f$ & Sum of Squares & Mean Square & $F$ & Sig. \\
Between Groups & 1 & 1.138 & 1.138 & 2.059 & .152 \\
Within Groups & 320 & 176.857 & .553 & & \\
Total & 321 & 177.995 & & & \\
Faktor Intrinsik dalam & $d f$ & Sum of Squares & Mean Square & $F$ & Sig. \\
Pekerjaan & & & & & \\
\hline
\end{tabular}



DOI: https://doi.org/10.47405/mjssh.v5i10.522

\begin{tabular}{lccccc}
\hline Between Groups & 1 & 0.61 & .061 & .114 & .736 \\
Within Groups & 320 & 171.574 & .536 & & \\
Total & 321 & 171.636 & & & \\
\hline
\end{tabular}

Jadual 22: Analisis Perbezaan Skor Mean Tahap Tekanan Kerja dengan Jantina

\begin{tabular}{lcc}
\hline Halangan Kerja dan Rumah & $\mathrm{N}$ & Mean \\
Lelaki & 134 & 2.6325 \\
Perempuan & 188 & 2.6910 \\
Total & 322 & 2.6667 \\
Struktur Iklim dan Organisasi & $\mathrm{N}$ & Mean \\
Lelaki & 134 & 3.0706 \\
Perempuan & 188 & 3.1238 \\
Total & 322 & 2.1016 \\
Peranan Pengurusan & $\mathrm{N}$ & Mean \\
Lelaki & 134 & 2.7544 \\
Perempuan & 188 & 2.5851 \\
Total & 322 & 2.6556 \\
Kerjaya dan Pencapaian & $\mathrm{N}$ & Mean \\
Lelaki & 134 & 3.0406 \\
Perempuan & 188 & 2.8989 \\
Total & 322 & 2.9579 \\
Hubungan di Tempat Kerja & $\mathrm{N}$ & Mean \\
Lelaki & 134 & 2.9096 \\
Perempuan & 188 & 2.7890 \\
Total & 322 & 2.8392 \\
Faktor Intrinsik dalam Pekerjaan & $\mathrm{N}$ & Mean \\
Lelaki & 134 & 3.0871 \\
Perempuan & 188 & 3.0591 \\
Total & 322 & 3.0707 \\
\hline
\end{tabular}

\section{Analisis Perbezaan Faktor Tekanan Kerja dengan Golongan Umur}

Jadual 23 dan 24 menunjukkan terdapat perbezaan yang bagi halangan rumah dan kerja $F(3,318)=$ 5.637; $\mathrm{P}=0.01,<0.05$, struktur iklim dan organisasi $\mathrm{F}(3,318)=5.725 ; \mathrm{P}=0.01,<0.05$, hubungan di tempat kerja $\mathrm{F}(3,318)=3.141 ; \mathrm{P}=.026,<0.05$, dan faktor intrinsik dalam pekerjaan $\mathrm{F}(3,318)=2.884$; $\mathrm{P}=.036,<0.05$. Manakala tidak terdapat perbezaan yang signifikan di antara faktor tekanan kerja bagi peranan pengurusan $\mathrm{F}(3,318)=1.657 ; \mathrm{P}=.176,>0.05$, kerjaya dan pencapaian $\mathrm{F}(3,318)=.644 ; \mathrm{P}=$ $.587,>0.05$ dengan golongan umur dalam kalangan kakitangan Hospital Kerajaan Sibu Sarawak.

Jadual 23: Analisis Perbezaan Faktor Tekanan Kerja dengan Golongan Umur

\begin{tabular}{lccccc}
\hline Halangan Kerja dan Rumah & $d f$ & Sum of Squares & Mean Square & $F$ & Sig. \\
\hline Between Groups & 3 & 10.120 & 3.373 & 5.637 & .001 \\
Within Groups & 318 & 190.296 & .598 & & \\
Total & 321 & 200.417 & & & \\
\hline Struktur Iklim dan Organisasi & $d f$ & Sum of Squares & Mean Square & $F$ & Sig. \\
\hline Between Groups & 3 & 9.258 & 3.086 & 5.725 & .001 \\
Within Groups & 318 & 171.415 & .539 & & \\
Total & 321 & 180.674 & & & \\
\hline Peranan Pengurusan & $d f$ & Sum of Squares & Mean Square & $F$ & Sig. \\
\hline Between Groups & 3 & 2.371 & .790 & 1,657 & .176 \\
Within Groups & 318 & 151.692 & .477 & & \\
Total & 321 & 154.063 & & & \\
Kerjaya dan Pencapaian & $d f$ & Sum of Squares & Mean Square & $F$ & Sig. \\
\hline
\end{tabular}



DOI: https://doi.org/10.47405/mjssh.v5i10.522

\begin{tabular}{lccccc}
\hline Between Groups & 3 & 1.047 & .349 & .644 & .587 \\
Within Groups & 318 & 172.308 & .542 & & \\
Total & 321 & 173.355 & & & \\
\hline Hubungan di Tempat Kerja & $d f$ & Sum of Squares & Mean Square & $F$ & Sig. \\
Between Groups & 3 & 5.123 & 1.708 & 3.141 & .026 \\
Within Groups & 318 & 172.873 & .544 & & \\
Total & 321 & 177.995 & & & \\
\hline Faktor Intrinsik dalam Pekerjaan & $d f$ & Sum of Squares & Mean Square & $F$ & Sig. \\
\hline Between Groups & 3 & 4.546 & 1.515 & 2.884 & .036 \\
Within Groups & 318 & 167.090 & .525 & & \\
Total & 321 & 171.636 & & & \\
\hline
\end{tabular}

Jadual 24: Analisis Perbezaan Skor Mean Faktor Tekanan Kerja dengan Golongan Umur

\begin{tabular}{lcc}
\hline Halangan Kerja dan Rumah & $\mathrm{N}$ & Mean \\
$15-40$ tahun (Belia) & 223 & 2.6953 \\
$41-55$ tahun (Pertengahan Umur) & 99 & 2.9026 \\
Total & 322 & 2.6667 \\
Struktur Iklim dan Organisasi & $\mathrm{N}$ & Mean \\
$15-40$ tahun (Belia) & 223 & 3.0455 \\
$41-55$ tahun (Pertengahan Umur) & 99 & 3.3347 \\
Total & 322 & 3.1016 \\
Peranan Pengurusan & $\mathrm{N}$ & Mean \\
$15-40$ tahun (Belia) & 223 & 2.5398 \\
$41-55$ tahun (Pertengahan Umur) & 99 & 2.5598 \\
Total & 322 & 2.6556 \\
Kerjaya dan Pencapaian & $\mathrm{N}$ & Mean \\
$15-40$ tahun (Belia) & 223 & 2.8368 \\
$41-55$ tahun (Pertengahan Umur) & 99 & 2.8989 \\
Total & 322 & 2.9579 \\
Hubungan di Tempat Kerja & $\mathrm{N}$ & Mean \\
$15-40$ tahun (Belia) & 223 & 2.8646 \\
$41-55$ tahun (Pertengahan Umur) & 99 & 2.9898 \\
Total & 322 & 2.8392 \\
Faktor Intrinsik dalam Pekerjaan & $\mathrm{N}$ & Mean \\
$15-40$ tahun (Belia) & 223 & 3.0938 \\
$41-55$ tahun (Pertengahan Umur) & 99 & 3.2316 \\
Total & 322 & 3.0707 \\
\hline
\end{tabular}

\section{Analisis Perbezaan Faktor Tekanan Kerja dengan Status Perkahwinan}

Jadual 25 dan 26 menunjukkan terdapat perbezaan yang signifikan di antara faktor tekanan kerja bagi halangan rumah dan kerja $\mathrm{F}(2,319)=1.172 ; \mathrm{P}=.011,<0.05$, struktur iklim dan organisasi $\mathrm{F}(2,319)=$ $3.299 ; \mathrm{P}=.038,<0.05$, peranan pengurusan $\mathrm{F}(2,319)=3.338 ; \mathrm{P}=.037,<0.05$, kerjaya dan pencapaian $\mathrm{F}(2,319)=1.942 ; \mathrm{P}=.045,<0.05$, hubungan di tempat kerja $\mathrm{F}(2,319)=6.647 ; \mathrm{P}=.002,<0.05$, dan faktor intrinsik dalam pekerjaan $\mathrm{F}(2,319)=3.515 ; \mathrm{P}=.031,<0.05$ dengan status perkahwinan dalam kalangan kakitangan Hospital Kerajaan Sibu Sarawak.

Jadual 25: Analisis Perbezaan Faktor Tekanan Kerja dengan Status Perkahwinan

\begin{tabular}{lccccc}
\hline Halangan Kerja dan Rumah & $d f$ & Sum of Squares & Mean Square & $F$ & Sig. \\
Between Groups & 2 & 1.462 & .731 & 1.172 & .011 \\
Within Groups & 319 & 198.955 & .624 & & \\
Total & 321 & 200.417 & & & \\
Struktur Iklim dan & $d f$ & Sum of Squares & Mean Square & $F$ & Sig. \\
\hline
\end{tabular}


DOI: https://doi.org/10.47405/mjssh.v5i10.522

\begin{tabular}{|c|c|c|c|c|c|}
\hline \multicolumn{6}{|l|}{ Organisasi } \\
\hline Between Groups & 2 & 3.661 & 1.830 & 3.299 & .038 \\
\hline Within Groups & 319 & 177.013 & .555 & & \\
\hline Total & 321 & 180.674 & & & \\
\hline Peranan Pengurusan & $d f$ & Sum of Squares & Mean Square & $F$ & Sig. \\
\hline Between Groups & 2 & 3.158 & 1.579 & 3.338 & .037 \\
\hline Within Groups & 319 & 150.905 & 473 & & \\
\hline Total & 321 & 154.063 & & & \\
\hline Kerjaya dan Pencapaian & $d f$ & Sum of Squares & Mean Square & $F$ & Sig. \\
\hline Between Groups & 2 & 2.086 & 1.043 & 1.942 & .045 \\
\hline Within Groups & 319 & 171.270 & .537 & & \\
\hline Total & 321 & 173.355 & & & \\
\hline Hubungan di Tempat Kerja & $d f$ & Sum of Squares & Mean Square & $F$ & Sig. \\
\hline Between Groups & 2 & 6.935 & 3.468 & 6.647 & .002 \\
\hline Within Groups & 319 & 171.060 & .536 & & \\
\hline Total & 321 & 177.995 & & & \\
\hline $\begin{array}{l}\text { Faktor Intrinsik dalam } \\
\text { Pekerjaan }\end{array}$ & $d f$ & Sum of Squares & Mean Square & $F$ & Sig. \\
\hline Between Groups & 2 & 3.701 & 1.850 & 3.515 & .031 \\
\hline Within Groups & 319 & 167.935 & .526 & & \\
\hline Total & 321 & 171.636 & & & \\
\hline
\end{tabular}

Jadual 26: Analisis Perbezaan Skor Mean Faktor Tekanan Kerja dengan Status Perkahwinan

\begin{tabular}{lcc}
\hline Halangan Kerja dan Rumah & $\mathrm{N}$ & Mean \\
Bujang & 78 & 2.6390 \\
Berkahwin & 244 & 2.7379 \\
Total & 322 & 2.6667 \\
Struktur Iklim dan Organisasi & $\mathrm{N}$ & Mean \\
Bujang & 78 & 3.2907 \\
Berkahwin & 244 & 3.3414 \\
Total & 322 & 3.1016 \\
Peranan Pengurusan & $\mathrm{N}$ & Mean \\
Bujang & 78 & 2.5999 \\
Berkahwin & 244 & 2.9545 \\
Total & 322 & 2.6556 \\
Kerjaya dan Pencapaian & $\mathrm{N}$ & Mean \\
Bujang & 78 & 3.0863 \\
Berkahwin & 244 & 3.3889 \\
Total & 322 & 2.9579 \\
Hubungan di Tempat Kerja & $\mathrm{N}$ & Mean \\
Bujang & 78 & 3.0877 \\
Berkahwin & 244 & 3.3889 \\
Total & 322 & 2.8392 \\
Faktor Intrinsik dalam Pekerjaan & $\mathrm{N}$ & Mean \\
Bujang & 78 & 3.2193 \\
Berkahwin & 244 & 3.8889 \\
Total & 322 & 3.0707 \\
\hline
\end{tabular}

\section{Analisis Perbezaan Faktor Tekanan Kerja dengan Tempoh Perkhidmatan}

Jadual 27 dan 28 menunjukkan terdapat perbezaan yang signifikan di antara faktor tekanan kerja bagi halangan rumah dan kerja $\mathrm{F}(2,319)=4.721 ; \mathrm{P}=.010,<0.05$, struktur iklim dan organisasi $\mathrm{F}(2,319)=$ 4.596; $\mathrm{P}=.011,<0.05$, peranan pengurusan $\mathrm{F}(2,319)=4.217 ; \mathrm{P}=.016,<0.05$, dan faktor intrinsik dalam pekerjaan $\mathrm{F}(2,319)=3.571 ; \mathrm{P}=.029,<0.05$. Mankala tidak terdapat perbezaan yang signifikan di antara faktor tekanan kerja bagi kerjaya dan pencapaian $\mathrm{F}(2,319)=.332 ; \mathrm{P}=.718,>0.05$, dan 

DOI: https://doi.org/10.47405/mjssh.v5i10.522

hubungan di tempat kerja $\mathrm{F}(2,319)=2.896 ; \mathrm{P}=.057,>0.05$ dengan tempoh perkhidmatan dalam kalangan kakitangan Hospital Kerajaan Sibu Sarawak.

Jadual 27: Analisis keputusan Perbezaan Faktor Tekanan Kerja dengan Tempoh Perkhidmatan

\begin{tabular}{|c|c|c|c|c|c|}
\hline Halangan Kerja dan Rumah & $d f$ & $\begin{array}{l}\text { Sum of } \\
\text { Squares }\end{array}$ & Mean Square & $F$ & Sig. \\
\hline Between Groups & 2 & 5.761 & 2.881 & 4.721 & .010 \\
\hline Within Groups & 319 & 194.655 & 610 & & \\
\hline Total & 321 & 200.417 & & & \\
\hline Struktur Iklim dan Organisasi & $d f$ & $\begin{array}{l}\text { Sum of } \\
\text { Squares }\end{array}$ & Mean Square & $F$ & Sig. \\
\hline Between Groups & 2 & 5.061 & 2.530 & 4.596 & .011 \\
\hline Within Groups & 319 & 175.613 & .551 & & \\
\hline Total & 321 & 180.674 & & & \\
\hline Peranan Pengurusan & $d f$ & $\begin{array}{l}\text { Sum of } \\
\text { Squares }\end{array}$ & Mean Square & $F$ & Sig. \\
\hline Between Groups & 2 & 3.968 & 1.984 & 4.217 & .016 \\
\hline Within Groups & 319 & 150.095 & .471 & & \\
\hline Total & 321 & 154.063 & & & \\
\hline Kerjaya dan Pencapaian & $d f$ & $\begin{array}{l}\text { Sum of } \\
\text { Squares }\end{array}$ & Mean Square & $F$ & Sig. \\
\hline Between Groups & 2 & .360 & .180 & .332 & .718 \\
\hline Within Groups & 319 & 172.995 & .542 & & \\
\hline Total & 321 & 173.355 & & & \\
\hline Hubungan di Tempat Kerja & $d f$ & $\begin{array}{l}\text { Sum of } \\
\text { Squares }\end{array}$ & Mean Square & $F$ & Sig. \\
\hline Between Groups & 2 & 3.174 & 1.587 & 2.896 & .057 \\
\hline Within Groups & 319 & 174.821 & .548 & & \\
\hline Total & 321 & 177.995 & & & \\
\hline Faktor Intrinsik dalam Pekerjaan & $d f$ & $\begin{array}{l}\text { Sum of } \\
\text { Squares }\end{array}$ & Mean Square & $F$ & Sig. \\
\hline Between Groups & 2 & 3.758 & 1.879 & 3.571 & .029 \\
\hline Within Groups & 319 & 167.877 & .526 & & \\
\hline Total & 321 & 171.636 & & & \\
\hline
\end{tabular}

Jadual 28: Analisis Perbezaan Skor Mean Faktor Tekanan Kerja dengan Tempoh Perkhidmatan

\begin{tabular}{lcc}
\hline Halangan Kerja dan Rumah & $\mathrm{N}$ & Mean \\
5 tahun ke bawah & 55 & 2.8394 \\
$6-10$ tahun & 94 & 2.7926 \\
10 tahun ke atas & 173 & 2.5434 \\
Total & 322 & 2.6667 \\
Struktur Iklim dan Organisasi & $\mathrm{N}$ & Mean \\
5 tahun ke bawah & 55 & 3.2033 \\
$6-10$ tahun & 94 & 3.2544 \\
10 tahun ke atas & 173 & 2.9863 \\
Total & 322 & 3.1016 \\
Peranan Pengurusan & $\mathrm{N}$ & Mean \\
5 tahun ke bawah & 55 & 2.5388 \\
$6-10$ tahun & 94 & 2.8250 \\
10 tahun ke atas & 173 & 2.6006 \\
Total & 322 & 2.6556 \\
Kerjaya dan Pencapaian & $\mathrm{N}$ & Mean \\
\hline
\end{tabular}



DOI: https://doi.org/10.47405/mjssh.v5i10.522

\begin{tabular}{lcc}
\hline 5 tahun ke bawah & 55 & 2.9192 \\
$6-10$ tahun & 94 & 3.0083 \\
10 tahun ke atas & 173 & 2.9428 \\
Total & 322 & 2.9579 \\
Hubungan di Tempat Kerja & $\mathrm{N}$ & Mean \\
5 tahun ke bawah & 55 & 2.9818 \\
$6-10$ tahun & 94 & 2.9220 \\
10 tahun ke atas & 173 & 2.7489 \\
Total & 322 & 2.8392 \\
Faktor Intrinsik dalam Pekerjaan & $\mathrm{N}$ & Mean \\
5 tahun ke bawah & 55 & 3.1111 \\
$6-10$ tahun & 94 & 3.2210 \\
10 tahun ke atas & 173 & 2.9762 \\
Total & 322 & 3.0707 \\
\hline
\end{tabular}

\section{Analisis Perbezaan Faktor Tekanan Kerja dengan Waktu Bekerja}

Jadual 29 dan 30 menunjukkan terdapat perbezaan yang signifikan di antara faktor tekanan kerja bagi halangan rumah dan kerja $\mathrm{F}(1,320)=26.661 ; \mathrm{P}=.000,<0.05$, struktur iklim dan organisasi $\mathrm{F}(1,320)=$ $46.427 ; \mathrm{P}=.000,<0.05$, peranan pengurusan $\mathrm{F}(1,320)=13.899 ; \mathrm{P}=.000,<0.05$, kerjaya dan pencapaian $\mathrm{F}(1,320)=28.504 ; \mathrm{P}=.000,<0.05$, hubungan di tempat kerja $\mathrm{F}(1,320)=12.034 ; \mathrm{P}=$ $.001,<0.05$, dan faktor intrinsik dalam pekerjaan $\mathrm{F}(1,320)=10.223 ; \mathrm{P}=.002,<0.05$ dengan waktu bekerja dalam kalangan kakitangan Hospital Kerajaan Sibu, Sarawak.

Jadual 29: Analisis Perbezaan Faktor Tekanan Kerja dengan Waktu Bekerja

\begin{tabular}{lccccc}
\hline Halangan Kerja dan Rumah & $d f$ & Sum of Squares & Mean Square & $F$ & Sig. \\
\hline Between Groups & 1 & 15.414 & 15.414 & 26.661 & .000 \\
Within Groups & 320 & 185.003 & .578 & & \\
Total & 321 & 200.417 & & & \\
\hline Struktur Iklim dan Organisasi & $d f$ & Sum of Squares & Mean Square & $F$ & Sig. \\
\hline Between Groups & 1 & 22.892 & 22.892 & 46.427 & .000 \\
Within Groups & 320 & 157.782 & .493 & & \\
Total & 321 & 180.674 & & & \\
\hline Peranan Pengurusan & $d f$ & Sum of Squares & Mean Square & $F$ & Sig. \\
\hline Between Groups & 1 & 6.413 & 6.413 & 13.899 & .000 \\
Within Groups & 320 & 147.650 & .461 & & \\
Total & 321 & 154.063 & & & \\
\hline Kerjaya dan Pencapaian & $d f$ & Sum of Squares & Mean Square & $F$ & Sig. \\
\hline Between Groups & 1 & 14.179 & 14.179 & 28.504 & .000 \\
Within Groups & 320 & 159.177 & .497 & & \\
Total & 321 & 173.355 & & & \\
\hline Hubungan di Tempat Kerja & $d f$ & Sum of Squares & Mean Square & $F$ & Sig. \\
\hline Between Groups & 1 & 6.451 & 6.451 & 12.034 & .001 \\
Within Groups & 320 & 171.544 & .536 & & \\
Total & 321 & 177.995 & & & \\
\hline Faktor Intrinsik dalam Pekerjaan & $d f$ & Sum of Squares & Mean Square & $F$ & Sig. \\
\hline Between Groups & 1 & 5.313 & 5.313 & 10.223 & .002 \\
Within Groups & 320 & 166.322 & .520 & & \\
Total & 321 & 171.636 & & & \\
\hline
\end{tabular}


Jadual 30: Analisis Perbezaan Skor Mean Faktor Tekanan Kerja dengan Waktu Bekerja

\begin{tabular}{lcc}
\hline Halangan Kerja dan Rumah & $\mathrm{N}$ & Mean \\
Waktu Pejabat & 197 & 2.4924 \\
Syif & 125 & 2.9413 \\
Total & 322 & 2.6667 \\
Struktur Iklim dan Organisasi & $\mathrm{N}$ & Mean \\
Waktu Pejabat & 197 & 2.8892 \\
Syif & 125 & 3.4364 \\
Total & 322 & 3.1016 \\
Peranan Pengurusan & $\mathrm{N}$ & Mean \\
Waktu Pejabat & 197 & 2.5431 \\
Syif & 125 & 2.8327 \\
Total & 322 & 2.6556 \\
Kerjaya dan Pencapaian & $\mathrm{N}$ & Mean \\
Waktu Pejabat & 197 & 2.7908 \\
Syif & 125 & 3.2213 \\
Total & 322 & 2.9579 \\
Hubungan di Tempat Kerja & $\mathrm{N}$ & Mean \\
Waktu Pejabat & 197 & 2.7265 \\
Syif & 125 & 3.0169 \\
Total & 322 & 2.8392 \\
Faktor Intrinsik dalam Pekerjaan & $\mathrm{N}$ & Mean \\
Waktu Pejabat & 197 & 2.9684 \\
Syif & 125 & 3.2320 \\
Total & 322 & 3.0707 \\
\hline
\end{tabular}

\section{Rumusan}

Kajian ini hanya dilakukan hanya untuk kakitangan-kakitangan yang berkhidmat di Hospital Kerajaan Sibu, Sarawak. Lokasi kajian yang dipilih adalah di Sibu, Sarawak. Hal ini kerana, Hospital Kerajaan Sibu merupakan sebuah hospital kerajaan yang terletak di Sarawak, Malaysia. Hospital Sibu merupakan hospital kedua terbesar di negeri Sarawak, Malaysia. Ianya merupakan hospital utama dan rujukan bagi Wilayah Tengah di Sarawak, Malaysia. Majoriti responden kajian ini adalah perempuan. Kebanyakkan responden adalah tergolong dalam golongan belia iaitu berumur 15 hingga 40 tahun. Selain itu, majoriti responden adalah telah berkahwin dan berkhidmat lebih dari 10 tahun ke atas serta bekerja pada waktu pejabat.

Kakitangan Hospital Kerajaan Sibu, Sarawak merasakan faktor struktur dan iklim organisasi menyumbang kepada faktor tekanan tertinggi. Dimana, pekerja kekurangan bimbingan dan sokongan daripada pihak atasan serta kualiti yang rendah dalam latihan dan pengembangan pengurusan. Mereka juga mengalami diskriminasi yang terlindung dan pilih serta kurang maklum balas mengenai prestasi sendiri di tempat kerja. Selain itu, terdapat kekurangan staf dan kadar pusingan ganti kerja yang tidak tetap serta perkongsian tugas dan tanggungjawab adalah secara tidak saksama. Ciri-ciri struktur dan rekabentuk organisasi yang tidak effisien dan kekurangan rundingan dan komunikasi juga membawa kepada faktor tekanan kerja yang utama.

Tahap tekanan kerja bagi kakitangan Hospital Kerajaan Sibu, Sarawak adalah berada pada tahap yang tinggi. Hal ini menunjukkan pekerja di Hospital Kerajaa Sibu mempunyai pemikiran negatif dan perasaan tertekan yang berpanjangan akibat dari masalah yang berkaitan serta menghadapi kesukaran dalam membuat keputusan. Kecekapan dalam pekerjaan juga semakin berkurangan berbanding dengan dahulu dan membawa kepada kualiti kerja yang semakin merosot. Mereka juga berpendapat bahawa perubahan tabiat makanan iaitu makan berlebihan atau kurang disebabkan masalah yang berkaitan dengan kerja serta sering berasa letih dari segi rohani, emosi dan fizikal selepas waktu bekerja. Bahkan, 
mereka berpendapat bahawa peningkatan kelalaian dalam menjalankan tugasan semakin meningkat yang membawa kepada ketidakpuasan terhadap kerja.

Hasil kajian menggunakan ujian Pearson Correlation menunjukkan perhubungan di antara faktor tekanan kerja iaitu struktur dan iklim organisasi, halangan rumah dan kerja, peranan pengurusan, kerjaya dan pencapaian, hubungan di tempat kerja dan intrinsik dalam pekerjaan dengan tahap tekanan kerja telah menunjukkan perhubungan yang signifikan sederhana.

Hasil kajian menggunakan ujian ANOVA terhadap tahap tekanan kerja dengan latar belakang demografi menunjukan tidak terdapat perbezaan yang signifikan antara jantina dengan tahap tekanan kerja. Hal ini menunjukkan tahap tekanan kerja yang dialami lelaki dan perempuan adalah sama tanpa mengira jantina. Manakala terdapat perbezaan yang signifikan antara kumpulan umur, status perkahwinan, tempoh perkhidmatan dan waktu bekerja dengan tahap tekanan kerja. Dimana, kumpulan umur iaitu pertengahan umur, individu yang sudah berkahwin, berkhidmat lebih dari lima tahun dan bekerja pada waktu syif mempunyai skor mean yang tinggi.

Hasil kajian yang menggunakan ujian ANOVA terhadap faktor tekanan kerja dengan latar belakang demografi menunjukkan tidak terdapat perbezaan yang signifikan antara jantina dengan faktor tekanan kerja iaitu struktur dan iklim organisasi, halangan rumah dan kerja, peranan pengurusan, kerjaya dan pencapaian, hubungan di tempat kerja dan intrinsik dalam pekerjaan. Hal ini menunjukkan semua faktor tekanan kerja boleh mempengaruhi jantina tidak kira lelaki atau perempuan.

Terdapat perbezaan yang signifikan di antara faktor tekanan kerja halangan rumah dan kerja dengan kumpulan umur. Ini kerana kebanyakkan pekerja yang berada dalam kumpulan umur pertengahan mempunyai lebih banyak tugas-tugas sama ada di rumah dan juga di tempat kerja. Seterusnya, terdapat perbezaan yang signifikan antara kumpulan umur dengan struktur dan iklim organisasi, hubungan di tempat kerja dan intrinsik dalam pekerjaan. Ini kerana dari segi tingkahlaku antara para pekerja yang masih muda usianya berbanding dengan para pekerja yang telah berusia iaitu dari segi prestasi seseorang pekerja dipercayai menurun seiring dengan peningkatan umur.

Hal ini disebabkan dari tahun ke tahun semakin ramai pekerja akan meningkat umur dan memerlukan pendekatan pengurusan yang berbeza. Contohnya kekurangan atau kualiti yang rendah dalam latihan dan pengembangan pengurusan dan tiada peningkatan diri melalui teknik baru, teknologi, inovasi atau cabaran baru. Manakala, tidak perbezaan yang signifikan di antara peranan pengurusan dan kerjaya serta pencapaian dengan kumpulan umur. Ini kerana terdapat tawaran kenaikan pangkat dan potensi untuk kemajuan dalam kerjaya tanpa mengira umur muda ataupun tua dalam mempertingkatkan tahap pencapaian peribadi.

Terdapat perbezaan yang signifikan di antara kesemua faktor tekanan kerja dengan status perkahwinan. Secara umumnya pekerja yang telah berumahtangga juga memerlukan kaedah yang mungkin berbeza dengan para pekerja yang masih bujang. Ini disebabkan keutamaan keperluan kehidupan bagi pekerja yang telah berkeluarga dengan yang masih bujang dalam banyak aspek adalah berbeza antara satu sama lain. Dimana, pekerja yang sudah berkahwin mempunyai lebih banyak komitmen yang perlu dilakukan sama ada di tempat kerja mahupun di rumah. Oleh itu, penawaran pakej pekerjaan yang lebih fleksibel sesuai dengan keperluan kumpulan pekerja boleh membantu mengekalkan motivasi kerja dalam kalangan para pekerja dalam melahirkan pekerja yang komited, berinovasi dan produktif.

Terdapat perbezaan yang signifikan di antara struktur dan iklim organisasi, halangan rumah dan kerja, peranan pengurusan dan intrinsik dalam pekerjaan dengan tempoh perkhidmatan. Ahmad Shukri menyatakan (2002) bahawa hubungan antara faktor kekananan dengan produktiviti adalah positif. Ianya bermaksud semakin lama seseorang itu berkhidmat atau bekerja maka semakin cekap dan efektif dalam pekerjaannya. Faktor pengalaman kerja telah memberikan kemahiran yang tinggi dan mematangkan cara individu bekerja. Hubungan antara senioriti dengan ketidakhadiran di tempat kerja dan pusing ganti pekerjaan pula adalah berbentuk negatif. 
Maksudnya, semakin lama seseorang itu berkhidmat dalam sesebuah organisasi maka semakin berdisiplin dan setia kepada organisasinya. Senioriti juga mempunyai hubungan yang positif dengan kepuasan kerja. Pekerja yang telah lama berkhidmat memperlihatkan tahap pencapaian tahap kepuasan yang lebih tinggi berbanding dengan para pekerja yang baru berkhidmat. Manakala tidak terdapat perbezaan yang signifikan antara tempoh perkhidmatan dengan hubungan di tempat kerja dan kerjaya serta pencapaian. Kerana setiap organisasi mempunyai prospek kenaikan pangkat yang jelas dan memunyai potensi untuk kemajuan dalam kerjaya bagi setiap pekerja.

Akhir sekali, perbezaan di antara faktor tekanan kerja dengan waktu bekerja mempunyai perbezaan yang signifikan. Menurut kajian yang dilakukan oleh Susan Ann et al. (2015), kerja syif malam menyebabkan pekerja sukar menguruskan hal keluarga, mengabaikan kesihatan diri. Hal ini kerana pekerja yang bekerja syif bekerja pada waktu pagi, siang atau malam dan mempunyai pusingan ganti yang tidak tetap berbanding dengan pekerja bekerja waktu pejabat. Menurut Susan Ann et al. (2015), mendapati bahawa kerja syif malam tidak hanya mengganggu kesihatan fizikal seseorang tetapi juga boleh memberi kesan terhadap kehidupan sosial seseorang pekerja. Sebagai contoh, seseorang yang bekerja pada syif malam tidak akan mempunyai masa yang mencukupi untuk menguruskan hal-hal yang berkaitan dengan keluarga, anak-anak, dan rumah berbanding dengan pekerja yang bekerja waktu pejabat.

Secara keseluruhan melalui kajian ini, kita dapat melihat pengaruh tekanan kerja kepada individu dan organisasi. Oleh yang demikian, maklumat-maklumat yang diperolehi melalui kajian ini dapat digunakan oleh semua pihak dalam meningkatkan prestasi dan mutu kerja di samping dapat mengurangkan dan mengatasi punca tekanan di tempat kerja. Walau bagaimanapun, kehadiran tekanan kerja tidak semua membawa implikasi yang negatif kepada pekerja tetapi timbul juga implikasi yang positif sekiranya ianya bertindak sebagai pendorong supaya seseorang itu lebih berusaha. Melalui kajian ini juga kita dapat melihat bahawa faktor tekanan kerja bukanlah berpunca daripada faktor luaran seseorang sahaja tetapi ia juga dipengaruhi oleh faktor dalaman seseorang. Oleh itu tahap tekanan yang dihadapi oleh setiap individu adalah berbeza mengikut sejauh mana ianya mempersepsikan tekanan itu boleh mempengaruhi dirinya. Sehubungan dengan itu, faktor jantina, umur, tempoh perkhidmatan, status perkahwinan dan waktu bekerja adalah faktor yang penting untuk diberi perhatian oleh pihak pengurusan.

\section{Penghargaan}

Penghargaan kepada Hospital Kerajaan Sibu, Sarawak atas kesudian untuk berkerjasama untuk menghasilkan Disertasi Bacelor FEM4959-A \& B sebagai memenuhi syarat bergraduat dalam Bacelor Sains (Pembangunan Manusia), Fakulti Ekologi Manusia, Universiti Putra Malaysia.

\section{Rujukan}

Ahmad Shukri Mohd Nain. (2002). Tingkah laku organisasi: Pengenalan tingkah laku individu. Universiti Teknologi Malaysia. Johor.

Aris Kasan, Fatimah Hanum Mohamad Hajari, Juwairiyah Jaafar \& Nordin Yusoff. (2012). Stres dalam perkhidmatan awam: Impaknya kepada prestasi dan kesejahteraan pegawai awam. Jurnal Psikologi dan Kaunseling Perkhidmatan Awam Malaysia, 7, 1-34

Asmawati Desa \& Siva a/l Subramaniam. (2002). Tekanan kerja iaitudi kalangan pensyarah: satu perbandingan di antara universiti awam dan university swasta. Pasca sidang seminar psikologi psima 2, $145-151$

Ayub, N., Bahari, F., \& Baco, B. S. (2008). Burnout dan komitmen terhadap organisasi di kalangan jururawat hospital. Jurnal Kemanusiaan, 12.

Azmi Mustafa. (2005). Tekanan dan kepuasan kerja di kalangan kakitangan Pusat Serenti. Latihan Ilmiah yang tidak diterbitkan. Universiti Kebangsaan Malaysia.

Brief, A.P, Schuler, R.S. \& Sell, M.V., (1981). Managing Job Stress. New York: Little Brown and Company. 
Cooper, J \& Robertson. (1987). International Review of The Industrial and The Organizational Psychology. USA: Wiley. (1978). Sources of TheManagerial and White Collar Stress. dlm. Stress at Work. Disunting oleh C. L Cooper \& R. Payne(eds). Chichester : John Wiley and Sons.

Cox, T., Boot, N., Cox, S. \& Harrison, S., (1988). Stress in Schools: An Organisational Perspective. Work and Stress, 2(4), 353-363

Emilia Zainal Abidin \& Noor Hassim Ismail. (2006). A study on occupational stress and coping strategies among medical and surgical ward nurses in hospital Universiti Kebangsaan Malaysia. (Unpublished Thesis Master). Universiti Kebangsaan Malaysia, Malaysia.

Haprizar Ashari, Norulkamar Ahmad \& Siti Aishah Abd Rahman. (2005). Komitmen organisasi di kalangan staf akademik: Hubungan dengan tahap stres. Pusat Pengurusan Penyelidikan. Universiti Teknologi Malaysia.

Harun Yahya (2019). Kaji punca stres kakitangan awam - CUEPACS. Berita Harian (Januri 20, 2019). Dilawati pada November 20, 2019, diperolehi dari https://www.bharian.com.my/berita/nasional/2019/01/521912/kaji-punca-stres-kakitangan-awamcuepacs

Khairul Bariah Ishak. (2003). Tekanan kerja, kepuasan kerja, strategi daya tindak, dan kesihatan mental dan kesihatan fizikal di kalangan jururawat. Latihan Ilmiah. Universiti Kebangsaan Malaysia.

Lauzan, G., (1963). Sigmund Freud :The Man and His Theory, (Terjemahan oleh Patrick Evan). Greenwich, Connecticut: Fawcett Publication Inc

Lazarus, R. S.,\& Folkman, S. (1966). Ways of coping questionnaire: Manual, test booklet and scoring key. United States of America: Mind Garden. Inc.

Lazarus, R. S., \& Folkman, S. (1984). Stress, appraisal, and coping. New York: Springer

Lazarus, R. S. (1966). Coping theory and research: Past, present, and future [Versi eletronik]. Psychosomatic Medicine, 55(3), 234-247. Lazarus, R. S.,\& Folkman, S. (1984). Stress, appraisal and coping. New York: Springer.

Lee, Hoo Nee. (2002). Hubungan Tekanan dengan lokus kawalan dalaman, personality jenis A dan kepuasan kerja di kalangan anggota PDRM. Latihan Ilmiah. Universiti Kebangsaan Malaysia.

Lim, Ngok Moi. (1998). Hubungan Tekanan dengan kesakitan fizikal dan peranan sokongan sosial sebagai perantara di kalangan pelajar. Latihan Ilmiah. Universiti Kebangsaan Malaysia.

Kamarudin, H. (2013). Faktor Tekanan Kerja Dalam Kalangan Kakitangan Mains Holdings Sdn. Bhd. Tesis.Open University Malaysia.

Martin Loosemore \& Tom Waters. 2004. Differences in occupational stress among professionals in the construction industry. Journal of Management in Engineering, 20, 126-132

Mandler (1979) A study of Stress and Psychology on Job Satisfaction among Universities Staff in Malaysia: Empirical Syudy. European Journal of Social Sciences, 8(1), 121-131.

Mahl (1971). Kaedah Penyelidikan Tingkahlaku Dalam Kalangan Pekerja. Kuala Lumpur: Dewan Bahasa dan Pustaka.

Md Zain Bidin \& Noor Hassim Ismail. (1999). Prevalens Tekanan Kerja Di kalangan Jururawat Hospital Angkatan Tentera Terendak. Jurnal Kesihatan Komuniti.

Mohd Fikri. (2003). Kajian pengetahuan kesihatan mental dan prevalen stres di kalangan paramedik Kementerian Kesihatan Malaysia. Tesis sarjana. Universiti Kebangsaan Malaysia

Narimah Abd. Razak. (2003). Hubungan di antara tekanan dengan kepuasan kerja dan kesannya terhadap strategi daya tindakan di kalangan jururawat Hospital Kerajaan dan Swasta. Latihan Ilmiah. Universiti Kebangsaan Malaysia.

Nora Azini Abidin (2003). Faktor-faktor yang Mempengaruhi Tekanan Kerja dikalangan Jururawat. Tesis. Universiti Malaysia Sarawak.

Nordin, N. and Hassan, M. M. (2019). Faktor-faktor yang Mempengaruhi Komitmen Prestasi Kerja dalam kalangan Penjawat Awam. Kajian Rintis di Jabatan Kemajuan Masyarakat, Negeri Pulau Pinang. Malaysian Journal of Social Sciences and Humanities (MJSSH), 4(7), 11-20. doi: https://doi.org/10.47405/mjssh.v4i7.303.

Raja Maria Diana Raja Ali. (2011). Faktor-faktor yang mendorong tekanan kerja (Stres) di kalangan guru-guru sekolah menengah di Daerah Pasir Putih. Tesis Sarjana. Open University Malaysia. Diperoleh dari http://eprints.oum.edu.my/666/1/faktor_raja_maria.pdf

Rees, D. \& C.L. Cooper. (1992). Occupational stress in health services workers in the UK. Stress Medicine 8: 79 - 90 . 
Rosidah Ramli (2016). Faktor yang Mendorong Tekanan Kerja di Kalangan Pekerja Sokongan di Pusat Perubatan Universiti Kebangsaan Malaysia. National Innovation and Invention Competition Through Exhibition (iCompEx'16)

Rohany Nasir \& Nor Eda Nusi. (2001). Tekanan kerja, tekanan rumahtangga dan komitmen kerjaya di kalangan pegawai wanita Polis Di Raja Malaysia. Jurnal Psikologi.

Rohany Nasir \& Fatimah Omar (2006). Kesejahteraan Manusia: Perspektif Psikologi. Kajian tekanan kerja dan kesihatan pekerja. Universiti Kebangsaan Malaysia. Selangor.

Rosli Hassan. (1996). Stress kerja: Kajian kes terhadap kakitangan bahagian kaunter di Jabatan Pendaftaran Negara Malaysia (JPN). Tesis. Universiti Malaysia.

Selye, H. (1976b). The stress of life (Rev. ed.). New York, NY: Mc GrawHill. Personaliti: Satu Kajian Ke Atas Eksekutif. Latihan Ilmiah. UKM.

Siu, O.L., I. Donald \& C.L. (1997). The use of the Occupational Stress Indicator (OSI) in factory workers in China. International Journal of Stress Management 4(3):171 - 182).

Spence and Spence (1956). Personality Stress, dalam V. Hamilton@DM. Warburton (eds), Human Stress and Cognition: An information Processing Approach, New York: John Wiley and Sons, Inc.

Thi, Lip Sam. (1998). A case study of factors causing stress to managers and executives at work. Tesis. Universiti Malaya.

Vitale, S. A., Varrone-Ganesh, J., \& Vu, M. (2015). Nurses working the night shift: Impact on home, family and social life. Journal of Nursing Education and Practice, 5(10), 70.

Zainah Ahmad Zamani \& Hamdan Mohd Ali. (2002). Kesihatan mental dan fizikal dan strategi daya tindak di kalangan pekerja sektor awam. Pasca Persidangan Seminar Psikologi PSIMA 2: Pusat Pengajian Psikologi dan Pembangunan Manusia, Universiti Kebangsaan Malaysia.

Zainah Ahmad Zamani \& Hamdan Mohd Ali. (2018). Separuh Pekerja Malaysia Bekerja Lebih Lapan Jam Sehari - Kajian - Semasa. Mstar (September 29, 2019). Dilawati pada November 15, 2019, diperolehi dari https://www.mstar.com.my/lokal/semasa/2011/11/08/separuh-pekerja-malaysiabekerja-lebih-lapan-jam-sehari--kajian 